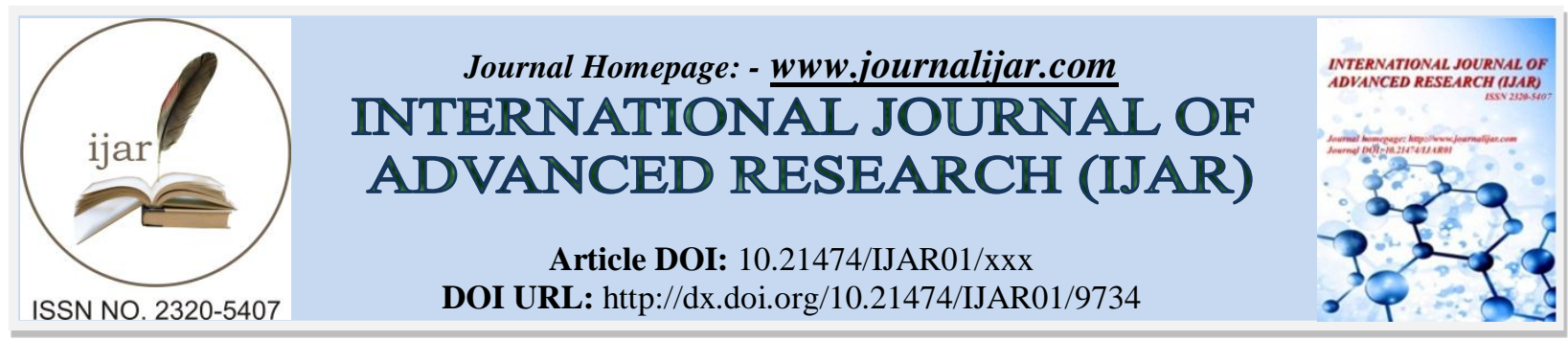

RESEARCH ARTICLE

\title{
THE ROLE OF ISLAMIC INTEGRATED EDUCATION PROGRAMME IN MORAL AND RELIGIOUS DEVELOPMENT OF LEARNERS IN SELECTED ISLAMIC SECONDARY SCHOOLS IN NAIROBI COUNTY.
}

Fatuma Kassim Mwatamu (Mrs.), Dr. P. Mumo and DR. A. Hashim. Dept. of Philosophy \& Religious Studies University of Nairobi.

\section{Manuscript Info}

Manuscript History

Received: 12 July 2019

Final Accepted: 14 August 2019

Published: September 2019

\section{Abstract}

The issue of moral decadence and secularization among the youth are subjects that cannot be avoided in Kenya today. The Muslim community has not been spared from these effects of secularization, globalization and poor religious educational systems, among the Muslim youths. These developmental conditions call for an urgent solution which is strongly believed to be best incorporated in our education systems.

This study therefore investigated the role of IIEP in moral and religious development of learners in secondary school. It is at this prime age that education systems need to mould future members of the society. It was therefore the objective of this study to find out the content of religious curriculum offered to the learners in order to achieve its objectives. We used the triangulation of theory and methodologies which ensured a thorough investigation into the problem. We employed religious sociological theory of Emile Durkheim and grounded theory which was a base for the development of the study methodology. The study was qualitative and quantitative in approach so as to ensure an in-depth investigation.

The study begins by giving the background of development of religious education in Kenya. In this context it shows the foundations of IIEP through different religious education systems and the need by the Muslim community to fulfil their religious obligations as stipulated in the Quran and prophetic hadiths. The main causes for these changes are highlighted in the process of development of the system.

Moreover, the study critically examined the curriculum in IIEP system. The curriculum is intended to impart the moral and religious skills. This curriculum to a larger extent is controlled by sectarianism in Muslim community. Through the study of curriculum in IIEP we found out that, religious knowledge is being emphasized a lot, Islamic moral values and practices are vital in these institutions. However, there is no harmonized curriculum as such and moral education is largely informal.

Lastly, the study explored the challenges facing the IIEP system in Nairobi. These challenges are strongly believed to hinder the progress and establishment of the system. Further, the study suggested possible recommendations for the future of IIEP. 


\section{Introduction:- \\ Chapter one \\ General introduction \\ Background of the Study}

Religion is the fabric with which human beings as individuals and communities, weave the web of their social existence. ${ }^{1}$ Religion here seems to take a bigger responsibility in humankind relationship which is social responsibility. It is through religion that a society identifies itself through similar norms and culture that binds them together in one distinct community. Islamic society stands on the foundations of unity and the concept of brotherhood. As such, it focuses on answering the basic needs of the individual and the interests he/she shares with others in terms of the family, the neighbourhood, the nation, and humankind in general. As the Qur'an attest, 'People were no other than a single community, but then they fell to differing' (Q10:19) ${ }^{2}$

In Islam it is believed that, God has endowed human with the capacity to admire good and despise what is evil. Human beings can make judgments based on this capacity; therefore they are able to plan out their own pattern of behaviour. Human has also been given free will to make choices whether good or evil. Religion such as Islam comes in to lay down what are good/virtues and bad/vices. If any one does a righteous deed, it is for the benefit of his/her own soul; if he does evil, it works against (his/her own soul) In the end you will (all) be brought back to your Lord (Q 45:15). Also, Let there be no compulsion in religion: Truth stands out clear from error (Q 2:256). ${ }^{3}$

Deeds illustrate the quality of will, whether it is good or evil, whether it follows truth, goodness and justice, or whether it is corruptible by its own desires. Finally, deeds will be measured in light of the individual's role as khalifah (vicegerent); and the Hereafter will represent and reflect the quality of one's will and deeds in this life. ${ }^{4}$ This clearly shows that, Islam as a religion insists on good conduct but without compulsion. Further, the Qur'an says, Allah commands Justice, the doing of good, and liberality to kith and kin, and He forbids all shameful deeds, and injustice and rebellion: He instructs you that you may receive admonition (Q16:90).

Islam puts a lot of emphasis in acquisition of knowledge. Education in Islamic Sharia is categorized as Fardh (obligatory) putting it next to prayers and fasting. ${ }^{5}$ There are various verses from the Qur'an and hadiths of the Prophet which encourages Muslims to seek knowledge. For instance, the Prophet said, "seeking knowledge is incumbent to all Muslims (male and female)". ${ }^{6}$

Islam encourages Muslims to acquaint themselves with religious knowledge and Muslim parents are vested with this responsibility. The origin of moral and religious values in Islam is the Qur'an and Sunnah. The Qur'an lays down the foundation of a religious system on purely ethical principles; hence there is no much to distinguish between Islam and Islamic ethics. Islamic morals are injunctions laid in the Qur'an and the Sunnah; these principles regulate man's life and govern his conduct towards his creator, fellow men and rulers. In Qur'an, ethics is closely connected with theology, and morality is enunciated as commands from God. Right conduct receives equal emphasis as right belief. The Qur'an says, "For We had certainly sent unto them a Book, based on knowledge, which We explained in detail, - a guide and a mercy to all who believe (Q7:52). The Prophet himself said, "I was sent only to complete the noble moral qualities." 7 It is these noble moral qualities that are enshrined in religious duties that Muslims have come to realize that most of the youth in the community lack. After realising that majority of the Muslims are lagging behind in 'catching up' with Western education, Muslims in major cities in Kenya like Nairobi embarked on 'empowering' their children through concentration in secular education. Recently they have realized that there are

${ }^{1}$ J.N.K Mugambi, "Religion and social Construction of Reality", (Nairobi, UoN Press, 1996) p. 5.

${ }^{2}$ Serdar A. "The Qur'an" (Turkey; Okyanus, English translation) p.104

${ }^{3}$ Ibid; pp. 248 \& 26

${ }^{4}$ Abusulayman, "Crisis in the Muslim Mind", p.48

${ }^{5}$ Othman Mujahid, "Challenges facing the teaching of I.R.E, Status and Way-forward" A Discussion Paper. (Nairobi, Sept, 2007 unpublished paper) p.2

${ }^{6}$ Sahih Muslim

${ }^{7}$ Zeno 1996, p.254 
various effects of this and imbalance in terms of youth development is a common manifestation. This imbalance is as a result of lack of or poor religious orientation. It is from this background that the Muslim community at large find the noble responsibility of redesigning the education system in a way that will address these imbalances. As Mugambi puts it,

"Through the processes of schooling, the African elite have also been largely alienated from African cultural and religious heritage. ... Schooling in Africa has been a process of cultural alienation. For development to occur and succeed schooling must be a process of cultural affirmation, in which the learners acquire relevant knowledge and skills to build and improve their own heritage" 8

Therefore, the Muslim community is now trying to impart these principles and values in its youth through the Islamic Integrated Education Programme. A programme intended to create a balance in education of the Muslim children taking care of both religious and other skills to enable them cope with life. This education is the education that puts emphasis in development of spiritual and moral aspect of the child and the worldly affairs. Initially Islamic Madrasa education was offered separately on privately organised institutions mostly attached to the mosques or even individual homes. The students would attend Madrasa separately after formal school hours; this is normally late in the evening for the day - scholars. Currently there is a trend in Kenyan schools especially in the urban and Muslim dominated areas; where Islamic private schools are established to provide holistic education that is religious and secular education simultaneously. The research examined the IIEP's role in moral and religious development of the learners, in line with the government's policy through the Ministry of Education Science and Technology (M.E.O.S.T) to offer religious education in schools.

\section{Statement of the Problem}

Religion plays a key role in enhancing moral and religious values in the Muslim community. Traditionally, children were taken to local Madrasa within the mosques to acquire religious knowledge and basic moral education which was highly regarded in the Muslim ummah. Later, Muslims realized that they are lagging behind in terms of modern education and job opportunities in the country therefore, embarked on secular education. The situation left majority of Muslim parents in a dilemma, most parents opted for secular education. Further, some parents were forced to ensure that their children concentrate on both secular and religious education, secular education only or religious education only, either way this caused the children to be disadvantaged in one area or another. After completion of secondary education it becomes very difficult for parents to take the teenagers back to the Madrasa hence, turn into stereotype Muslims. Today the Muslim community in Kenya has come to realize that a lot has been neglected in terms of moral and spiritual development of its youth enshrined in religious education, in the name of 'catching up with modernity.'

The small number of government and some private secondary schools offering IRE might be an effect of the nationwide lack of trained IRE-teachers. ${ }^{9}$ The trained teachers here mean teachers who have acquired formal education and teachers' training, majority of the Muslim teachers for a long period were Madrasa oriented with no secular education. The lack of IRE-teachers can leave schools with no alternatives than not offering IRE at all, or employ a non-Muslim teacher for IRE. Other reasons of the small number of schools offering IRE can be tracked to governmental directives of cut downs and savings. The Kenyan curriculum calls for the schools to keep down the costs. $^{10}$ This directive sometimes put schools in positions where they cannot afford CRE and IRE-teachers simultaneously and therefore most times favour CRE because of the numbers. Due to the need by the government to adjust its programmes structure, it is forced to cut down the costs for the state which leads to less money to the school system. Today, a school age child is expected to attend both the Madrasa and formal school at different timings and settings. Later, some children are forced to leave Madrasa and concentrate on secular education especially in secondary schools. The current national education system has been crafted so that children have no time to attend Madrasa classes. ${ }^{11}$

\footnotetext{
${ }^{8}$ J.N.K Mugambi \& Mary N. Getui (edts), "Religions in Eastern Africa under Globalization; Religions in East Africa in the Context of Globalization" - J.N.K Mugambi (Nairobi, Acton Publishers, 2004) p.16

${ }^{9}$ J. Svensson, “Divisions, Diversity and Educational Directives: IRE Teachers' Didactic Choices in Kisumu, Kenya. (British Journal of Religious Education. Vol. 32:3) p.249

${ }^{10}$ MOEST, "Development of Education in Kenya". (Nairobi, 2002)p.V

${ }^{11}$ Friday Bulletin, (Nairobi, Published by Jamia mosque, $10^{\text {th }}$ Sept, 2010) pp 1-2
} 
Otiende and Sifuna comment that, Islamic education also focuses on secular issues in life; this becomes useful in the acquisition of livelihood in the world and the attainment of truth and strengthening moral character. This form of education aims at creating different professionals who are able to earn a living in an honourable way, preserving the moral and spiritual aspect of it. The secular aspects of education are expected to supplement the spiritual function. ${ }^{12}$ Today, Muslims and Islamic schools have lost this focus. They are in a dilemma on whether their cardinal objective should be Islamic or secular. In addition, a majority of the Muslim parents opt to enrol their children in other schools not IIEP. This is due to not only financial constraint but uncertainty. Islamic schools are also in a crisis due to the demanding secular system of education. At most times the moral education of learners is neglected in order to complete the national syllabus. Moreover, if the IIEP School is not performing in national examinations, it means that Muslim parents would seek for other schools. If the IIEP system is not embraced by the Muslim community, opportunities that could have otherwise been available for the Muslim children to advance in society holistically might become foreclosed.

\section{Objectives of the Study:-}

The study is based on the following objectives:

1. To examine the origin and development of IIEP schools in Kenya and specifically in Nairobi County.

2. To investigate and compare the contents, quality, challenges and opportunities for the IIEP schools.

3. To determine the moral and religious role played by IIEP schools in development of students in secondary schools.

To establish the factors which hinder the progress of IIEP in Nairobi.

\section{Justification of the Study}

The initiative by the Muslim community to address Islamic principles and upbringing of children was a great idea through the IIEP. Schooling plays a big role in moulding individuals by enabling them to acquire skills and attitudes which are life long. According to Getui, a specific community or country's way of life is determined by what local situation has to offer and the approach that they use to mould its people to contribute to its community's sustenance. Getui recommended that, the training system through education adopted should be diversified, guiding the learners towards fulfilling the goals and all round entity meeting the physical, mental, moral and spiritual needs. ${ }^{13}$

Initially, the Madrasa education offered out of the formal school setting made parents opt to take their children to Madrasa at a tender age so as to acquire basic Islamic principles. Some parents at secondary school level stop their children from formal schools especially girls after attaining puberty stage for various reasons morality being key. Due to the introduction of IIEP there has been an improvement in the completion of secondary education especially in marginalized areas.

Kheir in his study, states that one of the challenges facing contemporary Muslim society is the crisis in Muslim education. He notes that, when the colonialists divided the system of education into two, the sacred and secular, majority of the Muslims got confused, and were divided into three groups. First were those who took their children to Madrasa only. Second were those preferred school only and third combined both Madrasa and school. He argues that, this confusion is still there. In addition, this crisis of Kenyan Muslim education has resulted in education contributed to lack of Muslim doctors, engineers, scientists, environmentalists, politicians, among others, who happen to be Muslims. ${ }^{14}$ It is therefore important to study the role of IIEP schools in the Muslim ummah in fostering religious and moral values among future professionals.

Studies have been conducted on IIEP at pre-school level; Early Childhood Development Education (E.C.D.E) in Kenya, for instance E.C.D challenges and solutions of IIEP, Importance of IIEP in Pre-school among others. Very little has been done on IIEP in secondary school. Most of the Islamic religious studies conducted at secondary level

\footnotetext{
12 J. Otiende \& D. Sifuna, “An Introductory History of Education.” (Nairobi, University of Nairobi Publication, 1992) pp. 141-142

${ }^{13}$ Getui, M, "The Religious Aspects of Secondary School Life and Their Effects on the Youths in Nairobi." (PHD Thesis 1993, Kenyatta University) Abstract.

${ }^{14}$ Abdallah Kheir, "Contemporary Challenges and Future Aspiration of Islamic Da'awah in Kenya." (Presented at International conference on Islam in Africa. International University of Africa, Khartoum: Sudan) pp. 20 - 21
} 
dealt with IRE in secondary schools, and to some extent Madrasa education. Kahumbi examined Muslim Education in Kenya with special reference to Madrasa in Nairobi. In this study he noted, the importance of Madrasa is underlined by its religious and moral training of its students. He recommended that, for moral and religious training to be carried out effectively, Madrasa the system needs to be streamlined in various aspects which have been found wanting. He further noted that, the integration of religious (Islamic) education with secular (modern) Muslim education and for the continued survival of the Madrasa system. ${ }^{15}$

Abusulayman noted that, at this beginning stage, the work of building for the future of the ummah will have to be done in the intellectual and educational spheres, as these are the ones from which the required reformation energies may be generated. The change in the Muslim might not be realized without proper planning and instructors, in order to design these proper elements are required. This cannot be achieved without a comprehensive and hybrid system of education. He further comments that, Islam is a religion which provides mankind with a reason for living, and ethical code by which to live. It provides mankind with insight into the seen and the unseen, the individual, society, and the universe and how man should relate to them. It also, protects the institution of the family and upholds the principles of justice. ${ }^{16}$ It is this perfect Islamic vision which is capable of treating the problems of modern materialistic society and the dangers it has produced, that is the moral bankruptcy of modern society. This reading justifies this study as it is probing into the moral role of IIEP in the Muslim community.

This research was intended to be useful to the Muslim community, religious leaders, policy makers and the school at large (teachers, students and parents). The research findings have provided knowledge on the IIEP which will be useful for the reviewers of the programme. This will enable the implementers to modify, introduce and eliminate some aspects that could affect the implementation of IIEP. It has also created an awareness of the existence of such a programme and eliminates negative attitudes towards the implementers and the system in Nairobi county and other areas of Kenya.

\section{Scope}

This research was carried out in Islamic integrated schools in Nairobi County. The four secondary schools selected to participate in the study included; where one was non- IIEP school was used as a control.

1. Wamy High school, in south B- boys' school (IIEP)

2. Rasul al Akram in Park Road- girl's secondary school (IIEP)

3. Muslim academy in Park Road- boys and girls school (IIEP)

4. Maina Wanjigi secondary school- boys and girls school (government secular school)

The study was conducted among boys and girls, IIEP teachers, school administrators, Muslim parents who have children in IIEP schools and other parents, some religious leaders and educationists. The data was gathered through questionnaires, interviews and observation from the respondents mentioned. The respective data instruments were given to students who are in the final grade of the secondary level, teachers and some parents depending on literacy skills. The research targeted the secondary schools which are IIEP oriented and one school which was non IIEP was used as a control in the sampled population in Nairobi.

\section{Literature Review}

In this section literature from the library and the internet, which contributes to the study were examined.

\section{Religion, Psychology and Society}

Pickering commented that Durkheim viewed religion in the context of the entire society. He acknowledged its place in influencing the thinking and behaviour of the members of the society. Religion contributes to health and continuation of society in general. Thus religion binds society's members, prompts them to affirm their common values and beliefs on a regular basis. He predicted that religious influence would decrease as the society passes on skills and values from one generation to the next. ${ }^{17}$ However, this process might be facing some challenges due to

\footnotetext{
${ }^{15}$ Newton Kahumbi, "Muslim Education in Kenya, with special Reference to Madrasa System in Nairobi." (M.A Thesis 1992, Kenyatta University) Abstract.

${ }^{16}$ A. AbuSulayman, "Crisis in the Muslim Mind" (Translation by Yusuf Talal DeLorenzo; USA, The International Institute of Islamic Thought, 1993) pp.85,88

${ }^{17}$ W.S. Pickering, "Durkheim's Sociology of Religion: Themes and Theories” (London 1984, Routledge and Kegan Paul Publication) pp. 193-194
} 
differences in situations and circumstances for instance what was applicable during the $7^{\text {th }}$ century might not be applicable in the $21^{\text {st }}$ century. This means that, what was interpreted during these two periods might differ, though the concept might not change. This reading is very important to the study as religion will persist in spite of secularization and one way of ensuring this is through the inclusion of religion in the system of education. He further noted that, all levels of education are significant to the society. This supports the study of IIEP at secondary school level. This is a stage which is as important as the formative stage in learners. Therefore, all stages of individual development have different and even similar causes of development. Durkheim does not expound on how the society should ensure that religion is preserved, because the thinking and behaviour is subject to change due to lapse of time and other factors besides religion. This research fills the gap through the study of moral and religious role of a religious education system.

In the psychological theory of Sigmund Freud (1856-1939), he conceived one of basic personality formed functions as engaged in the enforcement of moral standards acquired in childhood from authoritative adults. Freud believed that character was formed as early as five or six years and these see the first number of crucial psychosexual stages. $\mathrm{He}$ argues that all through life we are surrounded by other people and what they do. The person struggles with internal forces checked in the immediate, real and social. But part of the desire is to bring within what they are like. There is also identification with the other, to become like them. Freudian approach towards certain desires that is, from the instincts raises questions, and obsessions seems right and labels can be attached. ${ }^{18}$ The claim that personality is effectively made during the first years of life seems doubtful since so much variety of life comes from a few basic instincts displaced. The complexes alone hardly form attitudes to sexuality. There are a lot of life experiences later in the stage of development; it is adults who seem to be over more complexes in their traps and obsessions, when they are unable to identify what is acceptable and unacceptable in the society. It is also at this stage that religion plays a role in their lives in terms of changing character, offering a solution to the internal forces and identifies them with it. Moreover, this theory focuses on character or moral training only. Freud does not regard the adolescences and teenage stages as vital in character change and development.

Cohen et al note that, apart from the observable changes in people's behaviours, there are some other changes in behaviour that cannot be observed directly that is they are not manifested in overt behaviour. He identified three processes in attitude change; compliance, identification and internalization. He defines compliance as the ability to reward behaviour an individual likes and punish those they do not like. In identification one tries to act like another person because he identifies with him or her as a model. Finally, the internalization where certain attitudes and related behaviours are accepted as correct or desirable in and of themselves, an extreme example of this change is religious conversation. ${ }^{19}$ Therefore, children need to be nurtured in a particular way, for whatever they imitate from their seniors might influence their behaviour, in order to grow up as responsible members of the society, therefore the reading is relevant in this study as one of the aim involves nurturing morals. The reading does not elaborate on how religion can influence psychology to lead to a particular behaviour and behaviour change.

\section{Religion and Ethics}

Umaruddin commented on the ethical views of Al-Ghazzali, that man being the most exalted creation has a purpose which is to realize the moral end through the proper exercise of the qualities inherent in him. He has to develop the qualities which facilitate his moral progress and subjugate those which hinder it. ${ }^{20}$ In order to achieve moral end one has to build a good character which comprises all the virtues, most important the love of God. He notes that man has two forms, Khalq (the physical form) and Khulq (the spiritual form). Khulq (character) is the spiritual constitution of man, his natural self from which actions proceed spontaneously and easily, without much deliberation, hesitation or restraint on his part. ${ }^{21}$ It involves the ability to perform actions both good and bad, control over actions, the knowledge of actions and a state of self which is inclined towards both good and bad. He adds that, character is not to be identified with an action (character cannot be expressed through action only), or a faculty (it is amoral) or knowledge because none of these are in themselves good or bad except in relation to character. But at the same time, action, faculty and knowledge are essential to the functioning of character. Moreover, he notes that the fundamental

\footnotetext{
${ }^{18}$ Freudian Theory of personality at - http://www.personality-development.org/theories

${ }^{19}$ R.Cohen et al, "Psych City: A simulated Community (An Integrated Learning Experience in the Psychology of Community Participation)." (Sidney 1973, Pegamon Press Inc) p. 17

${ }^{20}$ M. Umarudin, “ The Ethical Philosophy of Al-Ghazzali.” (Aligarh; Pakistan 1962, Muslim University) p.163

${ }^{21}$ Ibid
} 
elements of inner constitution of man are reason or wisdom (aql or hikma), self-assertion (ghadab) and desire $\left(\right.$ shahwa). All these elements must work together in harmony. ${ }^{22}$

\section{Religion and Education}

According to Hadimi et al, the human soul has two powers; the first involves knowing and realizing. The power of knowing and realising consists of theoretical wisdom which is charged with acquiring experimental or scientific knowledge useful in understanding the reality and essence of the material world and practical wisdom responsible for the knowledge of ethics, which is useful for discriminating virtues from vices. The second is the causative and effective power which effects the accomplishment of useful and successful deeds. ${ }^{23}$ It acts upon the information acquired through the power of knowing. In general, knowledge teaches a person social responsibility, codifies behavioural principles and instructs on how to be useful to others. In Islam, life has been created with a purpose which is moral good; Q 23: 115, "Did you then think that We had created you in vain and that you will not be returned to Us?, 24

Religion plays a central role in the life of a Muslim. It is a practical system focusing on spiritual and temporal values. It is a complete code of human life which provides social behaviour. Kahumbi says that, "religions purport to give answer to everything. In that case, education (learning) is supposed to be inseparable from religion". ${ }^{25}$ Precisely he says, divine documents of Islam do not specify and or draw distinction to the kind of education a Muslim should pursue, rather it offers guidance to mankind to all aspects of life. IIEP is part and parcel of religion, it emphasize what religion directs in mankind.

It is the duty of a Muslim to follow the divine law in his or her daily activities as part of the society. He further says that Islam is integrated into the whole life of an individual and seeks to develop ones personality. ${ }^{26}$ The Madrasa is therefore an extension and form of partnership between the school and the home in imparting skills and values to individuals. A person could not be able to practice what he/she is not aware of therefore, knowledge becomes important. He adds that, in Islam, the necessary thing for a human being is to have Iman (belief), perform good deeds (amal) and do them with sincerity (Ikhlas). In order for a Muslim to have all these, knowledge becomes necessary. Knowledge informs us about the states and actions of spiritual heart (qalb) and the soul (ruh) ${ }^{27}$ The reading does not give us information on the processes of imparting these religious skills to the children.

Umarudin comments that, Islam is an ethical religion since, all its laws and injunctions in the holy Qur'an are based on the most equitable and moral foundation. It is concerned with inner conscience of man, certain practices and rites. ${ }^{28} \mathrm{He}$ further notes on Ghazzali's contention that, "knowledge is the basis of virtuous life." ${ }^{29} \mathrm{He}$ insists that, no spiritual and moral progress is possible without knowledge but all knowledge is not virtue and can lead one to a vice. Acquiring knowledge in Islam is an act of worship, Prophet Muhammad (p.b.u.h) said, "Acquisition of knowledge is a duty incumbent upon every Muslim."

Mugambi says that, schooling plays a significant role in the process of inculcating knowledge, skills and values. It also shapes the individual's religious orientation. He argues that, it is the religious curriculum which produces a generation conscious of the institutional value of religion through the content of syllabus that is given to learners. ${ }^{30}$ This content will determine the perception of religion internalized. Schooling is a vital organ in changing the community and a social institution, which creates an environment where individual, grow up in. Therefore, if the school environment is religious and very ritually oriented the individuals will view life from the same perspective.

${ }^{22}$ Ibid

${ }^{23}$ Muhammad Hadimi et al, "Ethics of Islam, $3^{\text {rd }}$ edition." ( Istanbul 2001,Wakf Ikhlas Publication) pp. 197-198

${ }^{24}$ Serdar A. "The Qur'an" (Turkey; Okyanus, English translation) p.173

${ }^{25}$ Newton Kahumbi in, "Muslim Education in Kenya" by S. Yahya and Bakari, S (edts); "Islam in Kenya." (Mombasa 1995,Proceedings of the National Seminar on Contemporary Islam in Kenya)p. 327

${ }^{26}$ M. Hamidullah, "Introduction to Islam.” (Islamic Repubic of Iran 1982, Ansariyan Publication)p. 85

${ }^{27}$ Ibid; p. 85

${ }^{28}$ Umarudin, M. “The Ethical Philosophy of Al-Ghazzali.” (Aligarh; Pakistan 1962, Muslim University) p. 260

${ }^{29}$ Ibid; p.78

${ }^{30}$ J.N.K.Mugambi, "Religion and Social Reconstruction of Reality." (Nairobi; Inaugural lecture on $26^{\text {th }}$ Sept, 1996, University of Nairobi Press) p. 13 
Otiende and Sifuna add that, education and training nurtures the mind of people, this is later is portrayed in the change of behaviour. ${ }^{31}$ Religion plays a key role in enhancing Islamic morals among Muslim youth. They add that, majority of Muslim philosophers seem to generally agree on the essence of Islamic education in moral and character training. Each lesson is expected to stress the moral aspects and every teacher is supposed to consider religious ethics above anything else. ${ }^{32}$ They do not separate morality from religion, he sees them as one. Traditionally, children were taken to local Madrasas within the mosques to acquire religious knowledge and basic moral education which is believed to be best imparted at a tender age. Today, a school age going child could be forced to attend both the Madrasa and formal school at different timings and settings. Later on, some children are forced to leave Madrasa and concentrate on secular education. ${ }^{33}$

Abusulayman supports this argument by saying that, the practical application of Islam's principles and values become ingrained in the education of all Muslims. Thus, the major arena for change in addition to the family and home environment is the educational institutions. ${ }^{34} \mathrm{He}$ further notes that, individual Muslim behaviour and the system of public legislation within Muslim society derive their legitimacy from a commitment to Islam and its goals, principle, purpose and values. The individual Muslim's actions and behaviour cannot ignore the regulations of the Islamic system. He adds that, life has a purpose which is moral good, the Prophet (p.b.u.h) said, 'he was sent only to complete the noble moral qualities'. ${ }^{35}$ This shows the importance of school in facilitating religious education. The IIEP schools targets bringing up individuals who are morally and religious upright who can fit and positively contribute in the society. The reading gives the Islamic perspective forgetting that there is also a need to formulate and find ways of addressing the principles of religious tolerance.

Moulton et al comments that, "if parents trust that their girls can learn in a low cost safe environment, they will send them to school. The combination of religious and quality secular education provides an added advantage since parents feel their girls and boys are obtaining a balanced education". 36 This reading shows a gap in knowledge; in terms of the reasons which could hinder children and especially Muslim girls to acquire education might be related to religious and moral issues. This could make parents mistrust educational institutions due to the religious orientation given to their children.

Isma'il Raji says, as prerequisite for the removal of dualism from educational system, which is in turn a prerequisite for removal of dualism from life, for the solution of the malaise of the ummah, knowledge ought to be Islamized. While avoiding the pitfalls and shortcomings of traditional methodology, Islamization of knowledge has to observe a number of principles constituting the essence of Islam. ${ }^{37}$ To recast the discipline under Islamic frame work encompasses; the unity of Allah, unity of creation, unity of truth, unity of knowledge, unity of life and humanity. He further comments that, without moral values as internal to and constitutive of it, the system is bound to deteriorate and become the prize for anyone who could contend for its success. ${ }^{38}$ This is precisely what the Islamic Institutions require, but more important we require qualified people who will implement this. We need to address the gap of implementers and identify their requirements.

AbuSulayman suggests that, the solution to the problems of ummah will be derived from the Islamic beliefs, values and inclinations. This also means understanding what those circumstances in regard to time and place in relation to Islam's heritage and experience. ${ }^{39}$ This is in terms of the significance of qualitative and quantitative change in

${ }^{31}$ J.Otiende \& D.Sifuna, “An Introductory History of Education.” (Nairobi, University of Nairobi Publication, 1992) p. 141

32 Ibid

${ }^{33}$ Friday Bulletin, $10^{\text {th }}$ Sept, 2010, pp.1-2

${ }^{34}$ A. AbuSulayman, "Crisis in the Muslim Mind" (Translation by Yusuf Talal DeLorenzo; USA, The International Institute of Islamic Thought, 1993) p.86

${ }^{35}$ Ibid

${ }^{36}$ Moulton et al (Feb, 2008,) p.7

${ }^{37}$ Isma'il Raji Al Faruqi, "Islamization of Knowledge: General Principles and Workplan.” (Brentwood, Maryland. International Institute of Islamic Thought, 1982) pp.9-10

${ }^{38}$ Ibid; p. 11

${ }^{39}$ A. AbuSulayman, "Crisis in the Muslim Mind" (Translation by Yusuf Talal DeLorenzo; USA, The International Institute of Islamic Thought, 1993) p.91 
human life through academic and intellectual approach. This should be possible to make the desired intellectual and civilization and transition from pastoral, agricultural and simple trading societies to the world of automation, communication and unending movement. This is also characterized by change in its potentialities and capabilities, its wealth and products and in the requirements and responsibilities of individuals, groups and political, social and economic systems. The experience is that which springs from real issues, problems and possibilities as viewed from perspective of Islamic thought, principles, purposes, values and teachings.

Brenner comments on the contemporary success of the Malian Madrasas which is a hybrid institution, dispensing instruction in Arabic with a curriculum whose structure, not its content, derived from a European model. ${ }^{40}$ This was a result of a long and difficult struggle, over the right or capacity to educate. The Malian pioneers of Madrasa system faced fierce opposition on two fronts, first the established Islamic notables wanted to resist any challenges to the Quranic and majlis system of education and second the state wanted to maintain control over formal schooling. Brunner further notes that, there was struggle in Mali between the Quranic schools, state schools and Madrasas. ${ }^{41}$ The Madrasa succeeded as they stress on religious values as opposed to secular values. The biggest challenge they faced was, they did not prepare students for any jobs other than teaching in Madrasas in turn. Attempts to modernize religious education pervade the Muslim world, in Africa and elsewhere. The control over schooling and differing visions are among challenges facing Muslims and certainly in Africa and Kenya not being an exception.

\section{The Kenyan Context}

In Kenya, one of the strategies of M.O.E towards Education For All (E.F.A) goals was to increase access and participation in secondary education. According to the Ministry of Education and Human Resource Development, girl child participation has increased according to the assessment. The issue of gender parity has featured prominently in the provision of education at all levels in Kenya. Several strategies and activities have been put in place to achieve positive results. The M.O.E personnel intend to move to communities and one of the ways of reaching the community is through the acceptance of IIEP in schools. ${ }^{42}$

The development of Islamic Integrated Education Programme (IIEP) schools is manifest in Nairobi, especially in areas where majority is Muslim such as Eastleigh. The IIEP involves the combination of the traditional Islamic Madrasa and the secular education. Williams notes that, "Since the $19^{\text {th }}$ century there has been tension between the two systems. In the recent decades a new dimension has been added to this struggle through schools which combine the two different modes of education." 43 The IIEP schools are not only religious based but they also target to mould an all rounded individual, in terms of religious and moral development and also excelling in secular education. The essence of Islamic education is to instil moral and character training; it is concerned with moral refinement and spiritual training.

Kindberg noted that, there are two goals of education in the Kenyan system which is connected to religious education. Educational goal number 4 aims 'to promote sound, moral and religious values.' 44 The purpose of this goal is to provide development of attitudes, knowledge and skills that could enhance the achievement of moral values, helping Kenyan children to grow up into good Kenyans with self discipline, self reliance and a feeling of integration into the society. Goal number 6 aims at 'promoting respect for and development of Kenya's varied cultures', its purpose is to inspire pupils build up an understanding of the past and the present cultures within the borders of Kenya. He insists that the primary purpose of IRE is to foster good Muslims. ${ }^{45}$ If IRE caters for religious development of the learners then why do we need to include IIEP? On the same note, Svensson observes that, "teachers in IRE feel stressed since their role requires both the way of schooling pupils into Islam as well as giving them opportunities to pass national exams with high grades. The Madrasa compliments IRE, but lots of pupils do

\footnotetext{
${ }^{40}$ L. Brenner, "Controlling Knowledge: Religion, Power and Schooling in a West African Muslim Society." (Bloomington Indiana University Press, 2001) p.1

${ }^{41}$ Ibid

${ }^{42}$ MOEST, "Development of Education in Kenya." (Nairobi, MOEST, 2004)

${ }^{43}$ Beth Williams, "Doctors and Imams: Investigating the Integrated Schools in Mombasa, Kenya." (Wake Forest University, 2009) pp 6-7

${ }^{44}$ Kindberg, M, "From Jesus to God to Muhammad and Allah, and Back Again - Kenyan Christian and Islamic Religious Education." (Bachelor Degree Thesis, 2010) p. 27

${ }^{45}$ Ibid
} 
not attend Madrasa at all" ${ }^{46}$ Many teachers according to Svensson have difficulties in schooling pupils into Islam since many lack the recitation of the Qur'an which is not part of the syllabus, further he notes that teachers are forced to teach about rather than into Islam, due to syllabus frames and the need to fulfil it before final examinations. ${ }^{47}$ This means that due to the need to complete the syllabus and prepare students for the national examinations mostly the religious and moral aspect of IRE in secondary schools is neglected. This is important to this study as this could be one of the reasons for the IIEP in Secondary schools in order to fill the gap of religious and moral aspect of IRE.

Kinyanjui conducted a study on the pattern of regional imbalances in the distribution of educational resources and opportunities in Kenya. The study revealed significant disparities between provinces and districts, along dimensions such as the proportion of primary-age group children actually in school, the distribution of secondary-school places, and the opportunity to continue with further education among others. ${ }^{48}$ These findings unfortunately went unexplained. The reading is significant in this study since; some of these disparities could have resulted from religious and moral issues which later mushroomed in the introduction of IIEP by private schools to address the challenges.

In Mombasa, M.R.C was established to improve the overall educational attainments of Muslim youth by implementing a two year, four stage approach to quality community based E.C.D.E which is the same, effective, relevant to local context and financially sustainable. It was established in response to a concern expressed by the Muslim community about their children's understanding of their local culture and religion and increasing their chances for later access to and success in formal education. Its mandate includes empowering and supporting communities to initiate and own community based E.C.D.E centres. ${ }^{49}$ The Young Muslim Association (Y.M.A) has also played a great role in supporting the IIEP at all levels of schooling. Since late 1980s and early 1990s the government has put the 8:4:4 curriculums which, sought to make education more responsive to the needs of the nation and learners. It sought to prepare the youth for self-reliance, self-employment, training in life skills and further education. The IIEP curriculum became effective in 1994, though the curriculum has not been harmonized. There is now a draft bridge curriculum from pre-school to lower primary. ${ }^{50}$ This indicate a problem especially at secondary school level, due to lack of a harmonized curriculum it pose a problem of objectivity, therefore many IIEP schools would be operating but not producing the required individuals at the end of the process.

\section{Theoretical Framework}

The study formulated theories through triangulation method in order to ensure that the subject of study is thoroughly investigated. In order to address this, two theories were discussed and their relevancy to the study was found.

The theory closer to the study was religious sociological theory of Emile Durkheim. Durkheim viewed religion with the context of the entire society and acknowledged its place in influencing the thinking and behaviour of the members of the society. According to Durkheim, religion is a social phenomenon that can be understood and be explained in sociological manner, a system of which the society is made conscious of itself. ${ }^{51}$ Further he sees religion as an institution which has various social functions. It is concerned with the ideals of the society, limits individuals and their selfish tendencies, curbs immoral acts and many of these functions are for the good of the society. Therefore, 'religion is a product of society which is associated with morality. ${ }^{52}$ Each person perceives morality in their own way, he further see that moral reality is divided into two; subjective and objective, where the objective is the common morality which applies to everyone collectively therefore social and subjective comprises of an infinite number of moralities, according to person's own judgement. ${ }^{53}$ Durkheim saw that, law and morality plays a major role in maintaining the equilibrium of society and adapting it to environment, which is also a role of

\footnotetext{
46 Jonas Svensson, “Divisions, Diversity and Educational Directives: IRE Teachers' Didactic Choices in Kisumu, Kenya.” (British Journal of Religious Education. Vol 32:3) p. 245

${ }^{47}$ Ibid; p. 258

${ }^{48}$ Kinyanjui K, "The Distribution of Educational Resources and Opportunities in Kenya." (UoN; Institute of Developmental Studies, Discussion Paper No.208, 1974) pp.14-15

${ }^{49}$ Islamic Integrated Education and Madrasa Resource Centre- http://www.akdn.org (25 ${ }^{\text {th }}$ June, 2010)

${ }^{50}$ Ibid

${ }^{51}$ W.S. Pickering, "Durkheim's Sociology of Religion; Themes and Theories." (London; Routledge and Kegon Paul Publication, 1984) p.193

52 Ibid; pp.194-195

${ }^{53}$ Ibid; p. 203
} 
religion. He held that religion, morality and law are the regulating forces in the society. Religion is viewed as an agent in the society which controls man's moral; it elevates man and makes him human. IIEP schools are religious based and therefore are social entities which facilitate acquisition of religious knowledge and teaches Islamic morals collectively. IIEP as a religious oriented system is used to impart ethical code, to enable the students to become responsible members of the society.

Durkheim argued that religion never concerns only belief, but also encompasses regular rituals and ceremonies. Rituals are necessary to bind together the members of religious group and they allow people to escape from mundane aspects of daily life into higher realms of experience. Islam is a ritualistic religion; therefore children need to be brought up with religious practices in order for them to become practical Muslims at a later stage in life.

The study will also be focused on the grounded theory, which is intended to lead to in-depth study of the problem. According to Corbin, "Grounded theory is a theory generating research methodology." 54 Further she gives more details, that grounded theory is integration in theory formulation which leads to in-depth understanding on how persons or organisations or communities experience and respond to events. It is a theory that is developed inductively from a corpus of data. This means that the resulting theory at least fits one dataset perfectly therefore, the theory emerges from the data (Glaser 1992). This contrasts with theory derived deductively from grand theory, without the help of data, and which could therefore turn out to fit no data at all. Grounded theory takes a case rather than variable perspective, although the distinction is nearly impossible to draw. This means in part that the researcher takes different cases to be wholes, in which the variables interact as a unit to produce certain outcomes. The basis theory development is actual data collected through qualitative research. It is largely influenced by emic understandings of the world: it uses categories drawn from respondents themselves and tend to focus on making implicit belief systems explicit. It is a construction from data; hence concepts form the foundation of the theory. The concepts are identified first from administration of instruments. These could be meanings given to specific events/incidents by 'open coding' since the text is intensively scrutinized. As the concepts are developed and analyzed, they form the basis of subsequent data collection. This means that, it is the events that give meaning and understanding to the concepts forming.

In the development of theory stage data is reduced into relevant categories for easy management. Concepts are grouped into categories through comparisons and questioning for commonalities; this is 'axial coding'. After the concepts have been grouped into categories, each earlier data concept becomes part of properties and dimensions of these subcategories (Theoretical sampling process). A core category is the constructed from identified concepts by selecting the construct most representative. It is the core category which forms the theory explaining the research in a large sense, an integrative concept but detailed in the individual categories' properties and dimensions.

\section{Hypotheses}

The research will test the following hypotheses in the study:

1. There is difference in moral and religious development of learners who attend IIEP schools and other secondary schools.

2. There is no significant difference between IIEP and IRE curriculum in secondary schools.

3. The negative perception by community is a major drawback in the progress of IIEP in Nairobi.

4. IIEP plays a significant role in moral and religious development of secondary school learners.

\section{Methodology:-}

This includes the description of subject from the population, the sample size, procedures and evaluation instruments. As indicated earlier by the theory, the research was qualitative in nature but in order to make quantitative determinations and estimates on range of factors, it has some quantitative approach. This formed triangulation in methodology used in this study.

\footnotetext{
${ }^{54}$ Corbin in, B.Somekh \& Lewin, (edts), "Research Methods in the Social Sciences." (New Delhi; Vistaar Publications, 2005) p. 49
} 
Figure 1: Shows triangulation methodology

Triangulation Design

\begin{tabular}{|l|}
\hline QUAN \\
Data and results
\end{tabular}

Data and results
$+$

INTERPRETATION

\author{
QUAL \\ Data and results
}

Quan- quantitative

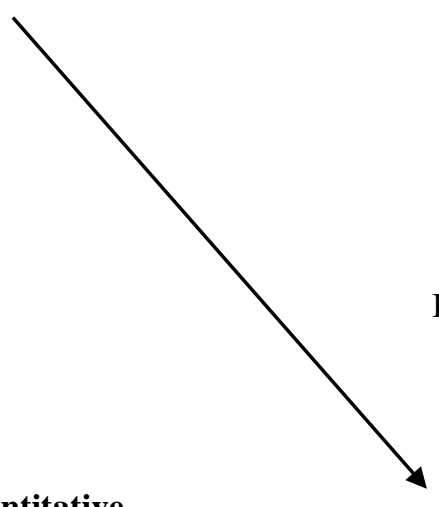

Qual- qualitative

subject

The research involved a field enquiry from selected secondary schools in Nairobi County. From these schools samples of students were taken from the final level of secondary education. This was in order to acquire varied skills and attitude due to exposure and experience. The subjects targeted are the form four students, both boys and girls ten students. Others include school proprietors, teachers, and focus groups with parents and religious leaders (Imams and / or kadhi).The population was multi- ethnic and had different educational background in primary schooling, some from IIEP primary schools, public schools, and non - religious private schools. One public no-religious based school was used as a control. The research used the theoretical sampling method.

\section{Evaluation Instruments/Data Collection Instruments}

The research was based on social survey model where representative samples and other smaller groups based on precise definition of the problem studied were used to make general statements on the population under study.

Data was generated through library search, internet, observations, questionnaires and interviews. The validity and reliability of the research materials were tested through comparing them to other tests which measured the same qualities through field tests and repeated reviews on reliability. This research compared the data in the schools investigated, review and sought opinion of experts.

\section{Design}

The research was focused on a goal - free model which was open and broad. This design was intended to enable the researcher acquire vast information on IIEP. It is an unconfined design which targeted to generate more outcomes/ variables and make modifications on moral and religious role of IIEP in secondary schools.

\section{Procedure}

The data was administered through a selected group of subjects in the population. The data collection instruments were pre-tested to examine their validity, reliability and clarity of the instruments and also generate concepts. Some problems were identified in the questionnaires, and they were reviewed. After the pre-test, the instruments were administered to the sampled groups. The sampled groups were selected through the stratified sampling method, so as 
to ensure that significant sub-groups of the population are represented. The IIEP schools selected ensured that both sexes are adequately represented, living standards among other variables.

The study involved students in secondary schools; the selection of the students was done randomly.

\section{Data Analysis}

The data collected was processed through the feedback and the results of the data collected in form of coding, memos, were presented through concepts/ categories and their dimensions. The collected data and information from the respondents (theoretical sampling) were used to develop the grounded theory on the moral and religious role of the IIEP. The verbatim quotations from the respondents which develop the concepts were used to approve or disapprove the existence of the moral and religious role in the IIEP secondary schools. These helped in generation of theory and develop different dimensions on the study. In addition the strengths, weaknesses, opportunities and threats of the programme were highlighted. The analysis generated basic concepts providing basis for further research. It also clarified areas in the programme which require urgent attention in terms of moral and religious development of learners.

\section{Chapter two \\ Origin and development of religious education in Kenya Introduction}

Education refers to the process of learning and acquiring knowledge and skills. It is also a process of imparting and acquiring change in behaviour. Colin A. says if education is viewed from the perspective of the relationship between individual and society, then education can be defined as 'the preparation of the pupil to take his place in society. ${ }^{, 55}$ Therefore religious education is the process of inviting the pupil to try to understand the religious heritages of his society and be able to assess the significance and value of this heritage for his own future development and mankind in general. ${ }^{56}$ Cox Edwin sees education as training to make judgements on the values that the society holds. According to him religious education is 'educating children to be informed and discriminating about the many manifestations of religion, and of near religion, which are likely to meet in a pluralistic society. ${ }^{57}$ We can therefore see that religious education involves the process of imparting the aspects of religion in learners, and developing of skills and attitude which will enable them to fit in the society. Religion as a part of education can show what various people believe and why, it also shows the effect of and give meaning to their belief.

Religion and morality are also closely related, this is because they complement each other. Each major world religion has its own prescriptive nature of its morality as the end and also justification of that particular religion. Mugambi notes, morality as one of the justification for religious adherence, that it is religion that provides solutions to all moral and ethical problems. ${ }^{58} \mathrm{He}$ further says ethics is a dimension of religion, that every culture has its established norms of conduct where the dominant religion becomes the custodian which the culture identifies itself. ${ }^{59}$ Cox defines norms in a sociological manner, that it is "setting out patterns or generalized forms of behavior" these are contents in a system that controls the way men interact. ${ }^{60}$ Gedge looks at the relationship between religion and morals. First, he shows how morals and religion interact as they both begin in the same area and are searching for the same discovery. Second he looks at religion and moral as independent entities, in a philosophical manner. That the argument is based on three reasons, first being no logical connection between the two, since it is man's sense of obligation therefore he 'ought' to do which implies transcendental personal will. Second, that the sole morally good reason to do good reason for doing good deeds is that it is good, therefore independent of religious

\footnotetext{
${ }^{55}$ N.Smart \& D.Horder (edts), "New Movements in Religious Education." ( Colin, A ; Relgious Education) (Great Britain; Billing \& Sons, 1975 ) p.23

${ }^{56}$ Ibid; p. 28

${ }_{58}^{57}$ Schneider, L, "Sociological Approach to Religion.” (U.S.A; John Wiley \& Sons, Inc, 1970) p. 38

${ }_{59}^{58}$ Mugambi, Op. cit p.12

${ }^{59}$ Ibid; p. 8

${ }^{60}$ Schneider, L, “Sociological Approach to Religion.” (U.S.A; John Wiley \& Sons, Inc, 1970) p. 39
} 
inclinations. Last, the empirical evidence is difficult to ascertain the association between moral and religion since it is possible for one to be moral without religion. ${ }^{61}$

\section{Development of Islamic Integrated Education Programme in Kenya}

The history of religious education in Kenya can be categorized into three periods. The first was before the colonial rule where, Africans had their own belief and practices. Children were brought up and taught about the Master Creator and His overall control of life at a tender age. Teachings were conducted through songs, dances, storytelling, myths, riddles and poems related to their origin. They also participated in rituals and ceremonies. This deposit of information was passed on from one generation to the next ensuring continuity of cultural practices and religious beliefs. Training was largely informal and was conducted by close family members; in the homes, fields and forests of their home areas. This primarily enabled children to adapt to their physical environment by transmitting and preserving cultural knowledge. ${ }^{62}$

The second period was during the advent of the Arabs and Europeans. Formal education among Muslims was first introduced by Arabs in the $11^{\text {th }}$ century. ${ }^{63}$ Most Arab influence was noted along the East African Coast where some indigenous Africans were converted to Islam. Some Arabs intermarried with the locals calling for the need to teach the new converts and also young children Islam. According to Trimingham Koranic schools (Madrasa education) were started in Muslim dominated towns. ${ }^{64}$ Children received religious education besides other subjects like Arithmetic, sciences, Arabic language, recitation of the Qur'an, Islamic morals (tarbiya), writing and other fundamental teachings of Islam. The settlement of Arabs also influenced the development of Swahili language. This was followed by the coming of European missionaries who introduced Western education in Kenya. Kaplan argues that, the foundation of modern education was laid by missionaries who introduced reading to spread Christianity besides other subjects. The first missionaries to settle at the East African Coast were the Portuguese Roman Catholics, who established monasteries as early as $1557 .{ }^{65}$ The second group comprised the Lutherans who were sent through the Church Missionary Society (C.M.S). According to Trimingham the first missionaries of the C.M.S arrived in 1877 while the Roman Catholics settled in $1879 .{ }^{66}$ The C.M.S Lutherans were the first Missionaries to start a mission school at Rabai in $1846 .^{67}$

The establishment of British rule in 1884 further led to the increase of Christian missionaries who established themselves at the Coast and travelled further into the interior of Kenya. They started schools with an aim of converting Africans to Christianity. The British colonialists supported the Christian missionaries by allowing them to expand the educational system which they also funded. The Madrasa education system drastically lost its influence, since it was only confined among the Muslims. The colonial government gave priority to the formal schools started by missionaries which used the Latin alphabet as opposed to the Madrasa system which used the Arabic alphabet. Most African Muslims feared taking their children to formal schools which were Christian based. The construction of the Kenya - Uganda (1896 - 1901) railway further led to the expansion of missionary activities to the interior of Kenya.

The third stage was after the Kenya independence where the three tier system(based on race) developed into three types of schools; the government schools for the Whites, private and / or missionary and harambee schools (self help schools). Private schools were best equipped. Some missionary schools were converted into government schools and harambee schools were geared towards increasing education for Africans, depending on the economy of location. Some of the specially favoured national schools are either missionary based or others which do not allow

\footnotetext{
${ }^{61}$ N.Smart \& D.Horder (edts), "New Movements in Religious Education." ( Colin, A ; Relgious Education) (Great Britain; Billing \& Sons, 1975 ) pp. 49-52

${ }^{62}$ Williams Beth Ann, "Doctors and Imams: Investigating the Integrated Schools in of Mombasa, Kenya." (Wake Forest University, 2009) p.4

${ }^{63}$ Ibid; p.5

64 Trimingham, S, "Islam in East Africa.” ( London; Oxford University Press, 1964)p.74

${ }^{65}$ Kaplan Irving, 1976

66 Trimingham, Op.cit. p.26

${ }^{67}$ Ochieng, W, "Themes in Kenyan History.” (Nairobi; East African Educational Publishers Ltd, 1990) p.148
} 
Muslims to practice their ideals. The disparities created by the colonial and post- colonial periods are still significant in Kenya. ${ }^{68}$

In the late 1980 the Islamic Integrated Education Programme (IIEP) in schools was initiated by the Aga Khan Foundation (AGF). The program gained support from Non Governmental Organisations (NGO's), Ministry of Education (M.O.E), Kenya Institute of Education (K.I.E) and other local and international bodies. This trend progressed from the pre-school to primary and now secondary schools. In the early 2000's the government schools have deteriorated while private schools prospered. IIEP schools are currently owned and managed by private individuals and religious organisations. Barlett et al comment that, initially the programme was pioneered by the Aga Khan foundation in Mombasa; they established the Madrasa Resource Centre (M.R.C). M.R.C was aimed at improving the overall educational attainments of Muslim youth through implementing a two-year, four-stage approach to quality, community-based early childhood education and development which was at the same time effective, relevant to local context and financially sustainable. The Madrasa pre-school is an extension of a home ensuring that young children are nurtured with Islamic morals (akhlaq). Islam is a way of life; therefore the teachings are practical in the whole life of an individual. The M.R.C. was also established to respond to the concern expressed by Muslim communities about their children's understanding of their local culture and religion. Need to increase their chances for later access to and succeed in formal education was also important. ${ }^{69}$

A report by Manani says, in Kenya the M.O.E adopted a Sector Wide Approach to Programme Planning (SWAP) to programme planning, which engages all stakeholders in education this is in order to attain national ownership, alignment of objectives, harmonization of procedures, approaches and a coherent financing arrangement. It also involves broad stakeholder consultations in designing a coherent and rationalized sector programme. After some discussions with Muslim leaders, it was agreed that the IIEP be developed and Madrasa and 'Duksi' teachers were to be trained on how to integrate religious learning (Madrasa) with secular education. ${ }^{70}$ This enables the Madrasa teachers to be able to apply the modern teaching and learning skills in their teaching. The programme has been accepted as a national programme for the Muslim dominated regions.

In a nutshell there was need to integrate the old Islamic Madrasa education system into the mainstream formal education, in order to provide hybrid system of education for holistic development of young Muslim. Muslim educationists in charge of IIEP need to improve on methodology and the modern teaching approach that could address the changes in the society. They should also look into the importance of the role to be played by the present generation by formulating right approaches and suitable means for the preparation of future generations provide energy and resources for constructive work and protect the same from depletion. Generate sound ideas from Islamic perspective; direct resources toward translating Islamic vision into material that may be used in the education and upbringing of youth. The first priority of the present generation to Muslim intellectuals and leaders should be the renewal of Islamic thought through education of sound Islamic perspectives. ${ }^{71}$

The government has accepted the system in order to achieve the Millennium Development Goal (MDG) of universal primary education. Most of the Muslim parents especially in areas of the country where majority is Muslim, would prefer their children to acquire basic skills in religion among which moral education is their priority. Such integration could enhance the literacy skills among Muslim boys and girls in such areas. IIEP schools in Nairobi are privately owned by individuals or groups.

\footnotetext{
${ }^{68}$ Court, D, “ The Education System as a Response to Inequality” (1979) p.14

${ }^{69}$ Evans, Judith \& Barlett, Kathy, "The Madrasa Earlychildhood Programme: 25 Years of experience." ( Report Published by Aga Khan Foundation, 2008) p.13

${ }^{70}$ Manani Henry, “Accelerated Learning: New Opportunities for Children at Risk Seminar." (Addis Ababa; A paper Presented by Ag. Deputy Director K.I.E, $15^{\text {th }}-17^{\text {th }}$ Nov, 2007) pp.6-7

${ }^{71}$ A. AbuSulayman, "Crisis in the Muslim Mind" (Translation by Yusuf Talal DeLorenzo; USA, The International Institute of Islamic Thought, 1993) p.84
} 


\section{Islamic Education}

Islam as a total way of life does not separate secular and religious life. Consequently, secular and religious educations are inseparable; they are integral parts of a whole. Islamic education is therefore supposed to support Islamic way of life.

The Arabic language has three terms for education, representing the various dimensions of the educational process as perceived by Islam. The most widely used word for education in a formal sense is ta'lim, from the root 'alima (to know, to be aware, to perceive, to learn), which is used to denote knowledge being sought or imparted through instruction and teaching. Tarbiyah, from the root raba (to increase, to grow, to rear), implies a state of spiritual and ethical nurturing in accordance with the will of God. Ta'dīb, from the root $a d u b a$ (to be cultured, refined, wellmannered), suggests a person's development of sound social behavior. What is meant by sound requires a deeper understanding of the Islamic conception of the human being.

Education in the context of Islam is regarded as a process that involves the complete person, including the rational, spiritual, and social dimensions. As commented by Al-Attas, the comprehensive and integrated approach to education in Islam is directed toward the "balanced growth of the total personality...through training Man's spirit, intellect, rational self, feelings and bodily senses...such that faith is infused into the whole of his personality." ${ }^{72}$ In Islamic educational theory knowledge is gained in order to actualize and perfect all dimensions of the human being. From an Islamic perspective the highest and most useful model of perfection is the prophet Muhammad, and the goal of Islamic education is that people be able to live as he lived. Education prepares humankind for happiness in this life, but rather "its ultimate goal is the abode of permanence and all education points to the permanent world of eternity". ${ }^{73}$ To ascertain truth by reason alone is restrictive, according to Islam, because spiritual and temporal realities are two sides of the same sphere. According to the findings many Muslim educationists, parents, and other stakeholders argue that favouring reason at the expense of spirituality interferes with balanced growth. Exclusive training of the intellect, for example, is inadequate in developing and refining elements of love, kindness, compassion, and selflessness, which have an altogether spiritual ambiance and can be engaged only by processes of spiritual training.

Islamic education is uniquely different from other types of educational theory and practice largely because of the allencompassing influence of the Koran. The Koran serves as a comprehensive blueprint for both the individual and society and as the primary source of knowledge. The advent of the Koran in the seventh century was quite revolutionary for the predominantly illiterate Arabian society. Arab society had enjoyed a rich oral tradition, but the Koran was considered the word of God and needed to be organically interacted with by means of reading and reciting its words. Hence, reading and writing for the purpose of accessing the full blessings of the Koran was an aspiration for most Muslims. Thus, education in Islam unequivocally derived its origins from a symbiotic relationship with religious instruction.

According to Islamic faith, human was created was created by God for a divine purpose. In order to fulfil this purpose God has provided him with reason and free will which raises him to a higher level than other creatures. This has to be enhanced through acquisition of knowledge in order to have desirable relationship between him and his fellow men and also his Master Creator. Islamic knowledge has both practical and spiritual applications. It provides humankind with a reason for living and with an ethical code by which to live. It affords humankind with insight into the fitrah (natural inclinations of man) and the dimensions of its universal relationships; with the seen and the unseen, the individual, society, and the universe. Islam provides humankind with the foundations for a stable society, progress, security, and world peace. ${ }^{74}$

Islamic education started before the death of the Prophet Muhammad (p.b.u.h) where the main aim at this stage was to preserve the Qur'anic verses for prosperity. The Prophet taught Qur'an among his followers, urging them to seek knowledge. Madina was the first centre of Islamic learning as well as a social cultural centre.

\footnotetext{
${ }^{72}$ Al-Attas, Syed Muhammad, "Preliminary Thoughts on the Nature of Knowledge and the Definition and Aims of Education; In Aims and Objectives of Islamic Education.” (Jeddah; King AbdulAziz University, 1979) p. 158

${ }^{73}$ Nasr, S. S. "Science \& Civilization in Islam." 2nd ed. (Cambridge, United Kingdom: The Islamic Texts Society, 1987)p.7

${ }^{74}$ AbuSulayman, Op.cit; p.88
} 
After a period of time a three tier system of education developed including the Koranic school (Kuttab) which was elementary school, the Madrasa (high school), and the Institute of Higher learning around $9^{\text {th }}$ and $12^{\text {th }}$ century which was equivalent to modern universities. This was the period that Islamic civilization was at its peak ('Golden Age'), these institutions were found in Baghdad, Basra, Kufa, Cairo, and Cordova among others.

\section{Aims of Islamic Education}

As we have mentioned earlier, secular and religious education is inseparable in Islam, the major aim in education is to enhance a total way of life in mankind. Education in Islam also aims at equipping an individual to live in this world according to the Divine Command as revealed in the Qur'an and the Sunnah of the holy Prophet. Therefore, the aim is to teach Qur'an and Sunnah for cultural and literary value, produce faith and code of behaviour. Further, Islamic education provides or nurtures character and moral training with an objective of producing a good Muslim; a person whose spiritual, intellectual, emotional and physical growth are well balanced. As Umaruddin puts it, 'in order to form beautiful character and the development of qualities which are conducive, wisdom, self assertion and appétit ion are fundamental. They must work together and be in the correct proportion. ${ }^{75}$

Islamic religious education also aim at nurturing learners in making rational judgements about facts through giving certain experience and enable them to see in the light of religion. This enables learners to interpret religion in their contemporary situation and enhance decision making in attaching value and meaning to religion. According to Cox, it educates learners to be informed and be able to discriminate about many manifestations of religion and other religions which they are likely to meet in a pluralistic society; religious tolerance. ${ }^{76}$

Finally to help learners have a religious view of life and to make up their own decisions regarding religious questions (free will). These help learners to become independent and responsible members of the society in future as they take their different roles.

\section{Islamic Religious Education in Kenyan Secondary Schools}

We are going to study the development of Islamic Religious Education in Kenya through the religious education system in Kenyan secondary school curriculum and dualism in the system of education.

\section{Islamic Religious Education}

Religious Education in Kenyan secondary schools curriculum is categorised as a humanity subject. Religious education in the curriculum is a product of the recommendations of educational commissions before and after independence in Kenya. According to the recommendation of Kamunge commission on religious education, "Religious instruction should be handled as an academic subject on educational lines, dissociated from sectarian objectives..." ${ }^{, 77}$ This clearly separates the religion and education in approach, the aim is more educational than religious.

Observing the curriculum for the secondary schools, the Kenya Institute of Education has set up a list of national goals of education and two of the goals are closely related to religion and religious education. Goal number four which aims to "promote sound moral and religious values." "The purpose of this goal is to provide for development of attitudes, knowledge and skills that enhance achievements of moral values, helping the Kenyan children to grow up into good Kenyans with self-discipline, self-reliance and a feeling of integration in society." 79 Goal number six which aims to "promote respect for and development of Kenya's rich and varied cultures." ${ }^{\text {" The }}$ purpose of this goal is to develop positive attitudes among the pupils and build up an understanding of the past and the present cultures within the borders of Kenya, and their valid place in the contemporary society with religious tolerance. Having the traditional values in mind the pupils should be given the possibility to develop an ability to

\footnotetext{
${ }^{75}$ Umarudin, M. "The Ethical Philosophy of Al-Ghazzali.” (Aligarh; Pakistan 1962, Muslim University) p.88

${ }^{76}$ Schneider, L, "Sociological Approach to Religion.” (U.S.A; John Wiley \& Sons, Inc, 1970) p. 37

${ }^{77}$ Republic of Kenya, 1964 p.11

${ }^{78}$ Republic of Kenya, MOEST. "Secondary Education Syllabus Volume 3, 2002 p. VII

${ }^{79}$ Kindberg, M. "From Jesus and God to Muhammad and Allah, And Back Again-Kenyan Christian and Islamic Religious Education." (Bachelor Degree Thesis, 2010) p. 27

${ }^{80}$ Republic of Kenya, MOEST. "Secondary Education Syllabus Volume 3, 2002, p. VII
} 
blend them with the ongoing changes in cultural (and religious) requirements in the building of a modern Kenyan state. $^{81}$

Apart from the national goals of education, Secondary education has specific objectives. The specific objectives which are religious are "promote harmonious co-existence among people of Kenya" and "develop mentally, socially, morally, physically and spiritually.",82

Looking at the religious education in Kenyan curriculum, we can therefore conclude that religious education is used as an instrument to train and impart knowledge and skills which enables Kenyans to live as a community. All the aspects of individual development are taken care of so as to contribute positively in the society in future. The main concern here is the goals are right in terms of religious development but, if the more educational than religious it results in preparation of learners to pass the final exams and not religious development.

IRE in secondary school aims to expose the pupils to fundamental principles and teachings of Islam. The syllabus mentions Islam as more than just a religion, Islam must be seen as a way of life. The language of instruction is English, this limits the instructor even when it comes to the recitation of Qur'an which must be read with its English translation. The syllabus consist eight main areas: Quran, Hadith, Devotional Acts, Pillars of Iman (faith), Akhlaq (morals), Muamalat (relationship), History of Islam and Muslim Scholars. ${ }^{83}$

\section{Islamic Integrated Education Programme - An overview}

Here we briefly discuss the birth of Integration of religious curriculum, in other words IIEP. This is due to the challenges experienced by Muslim community as discussed earlier in an attempt to solve the Muslim education problem.

\section{Dualist}

\section{SYSTEM OF EDUCATION}

Due to the challenges of life in the current world, countries and people tend to compete with each other to attain a developed and progressive community. It is assumed that it is only through a modern system of education that people can intellectually and economically develop. As a result, the majority of traditional institutions in Muslim communities, such as Madrasa, continue to be institutions that only teach Islamic knowledge, whilst secular institutions are more popular, providing modern education with some religious elements or values. The separation between these two patterns of education, referred to as the "dualist system of education" is the main problem faced by Muslim society. Rahman states that the 'duality of loyalty to religion and to worldly affairs' results in a "secularist" state of mind. ${ }^{84}$ Secularism destroys the purity and universality of all moral values and is wholly atheistic. Rahman sees that this duality has resulted in the decline and stagnation of Muslim intellectualism. He states that this situation started in the thirteenth/fourteen century when madrasah rejected "rational sciences" in its curriculum; one of the reasons being the opposition of important religious imams, such as Al-Ghazzali, to the learning of philosophy. Muslim society then wrongly perceived that any scientific knowledge or works should be avoided. $^{85}$

According to the findings, currently some of the Muslims in Nairobi and Kenya at large are trying to imitate or adopt the West's intellectual ideology or pattern of civilization, as long as "Islamic" elements are attached to it. We found out that, certain modern Muslims try to practice what they call "Rationalistic Islam" or "Islamic Rationalism", eliminating the orthodox way of learning practiced since the 14th century. Islam affirms logic as the truth of the truth $(a l-a q q)$, but its role must be as a ladder that leads man to the divine. Reason results from reflection of the intellect ( $a q l$ ) and it should not be misled by passions and the nafs. Reason and intellect are both instruments for reaching the divine truth, but if humans use only pure reason it will act as a veil to the divine, because of its limitations in terms of the super rationality of the divine. Qur'an has not provided detailed so, humans should use their intellect based on the hierarchy of knowledge and the harmony between faith and reason.

\footnotetext{
${ }^{81}$ Kindberg; Op.cit, Ibid

${ }^{82}$ Republic of Kenya; Op.cit

83 Ibid

${ }^{84}$ Rahman, F. "Islam and Modernity: Transformation of an Intellectual Tradition." (University of Chicago Press, 1982) p. 47

${ }^{85}$ Ibid; p. 15
} 


\section{Integration of Religious Curriculum in Nairobi}

Initiative has been taken by Muslims in Nairobi who are interested in implementing a purely Islamic character in education by taking actions in which the initial steps were to integrate the dual system, firstly at E.C.D.E level, primary level and now secondary schools. In order to achieve quality education there is need to restructure the training of teachers. ${ }^{86}$

The moral and spiritual elements should be taught in Muslim education since Islam does not accept the dichotomy of secular education. It focuses on developing an integrated human personality: spiritual, physical, intellectual, social and moral. Human personality in the Islamic concept is a balanced personality based on the basic beliefs about the purpose of human creation as well as the basic duties of Islam. Faith (Iman) is the basis of all Islamic duties. These are in forms of worship such as prayer, fasting, pilgrimage, including all Muslim actions that are based on good intentions.

Apart from Islamic curriculum IIEP schools also provide modern education which equips the learners with competent skills in order to earn their living in future. This is achieved by providing secular and religious education within the same settings.

Aims and Objectives of Islamic Integrated Education Programme in Secondary Schools

The chief aims of the Integrated Education System are to solve the problem of dualist education, inculcate Islamic elements across the curriculum, and provide a holistic education that addresses the physical, spiritual, and emotional needs, through the delivery of both revealed and acquired knowledge.

The Holy Qur'an says in sürah Al-Mā'idah verse 3 and surah Āl- 'Imrān 110;

'This day I perfected your religion for you, completed my favour upon you and have chosen for you Islam as your religion'. $(\mathrm{Q} 5: 3)^{87}$

'You are the best of peoples, evolved for mankind enjoining what is right, forbidding what is wrong and believing in God'. (Q 3: 110) $)^{88}$

Imam Al-Ghazzali affirmed that the main aim of education should be to become closer to Allah the Almighty. Inculcation of good morals and eternal values is also important, so as to be intoned with the Infinite. In other words, the immediate aim of learning is the purification of the soul. It is also important to arouse moral consciousness among students, in order to train them on the proprieties of social life. It supposed to be in line with the purpose of creating human beings, and education should be a preparation for eternal life without neglecting the worldly side. ${ }^{89}$ We can see that Al-Ghazzali stressed the great importance of purifying humans spiritually through the cultivation of good morals and values. By this, one may develop a great communion with Allah the Almighty. Although spiritual aspects seem to be the priority, worldly life should not be neglected, since through a pure spirit humans will be able to accomplish their duty in this world so as to bring justice, balance and order to all God's creation.

According to the findings, the aims of IIEP generally can be summarized as follows;

To inculcate the religious development of learners, through imparting skills and values in line with Islamic beliefs and principles. As well as providing quality secular education to enable learners to survive in the world.

To nurture good moral values in learners in order to develop good habits, for which religion is essential because it is the civilizer of morals and purifier of the soul as well as the promoter of a spirit of cooperation in society to ensure desirable means of livelihood in Kenya and elsewhere.

To provide the teachings of Holy Qur'an as the first step of education, providing experiences which are based on fundamentals of Islam as embodied in Holy Qur'an and Sunnah, which cannot be changed.

\footnotetext{
${ }^{86}$ Al-Ashraf, "New Horizons in Muslim Education.” (London; Hodder and Stoughtn, 1985)pp.92-93

${ }^{87}$ Serdar A. " The Qur'an” (Turkey; Okyanus, English translation) p.56

${ }^{88}$ Ibid; p.36

89. Al-Ghazzali, Abu Hamid Muhammad Trans. "The Revival of Religious Learning.”(Vol. I \& II. Lahore, India: Kazi Publications.) p.26
} 
To provide experiences in the form of knowledge and skills with clear understanding in reference to the changes in society. Mould individuals who will integrate well in the wider society.

To develop understanding that knowledge without a basis in faith and religion is incomplete education and commitment towards the basic values which have been prescribed in religion and scripture

To encourage international brotherhood and consciousness irrespective of differences in generations, occupations and social class amongst the person who are knit together by a common religion and faith.

To develop qualities of a good human, universally accepted in the society, with faith and religious tolerance.

Figure 3:-Shows the summary of the general aims of IIEP

\section{Attained happiness in this world \& eternal world}

(God)

Attained happiness in this world \& etenal world

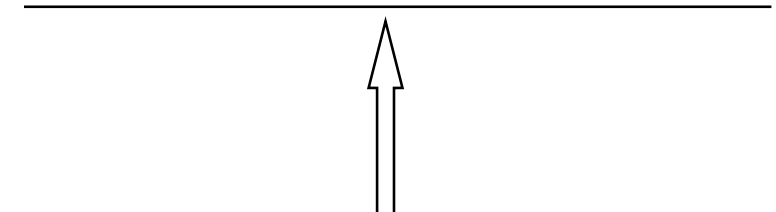

Brotherhood, love and good character

(Ability to live with others peacefully - society)

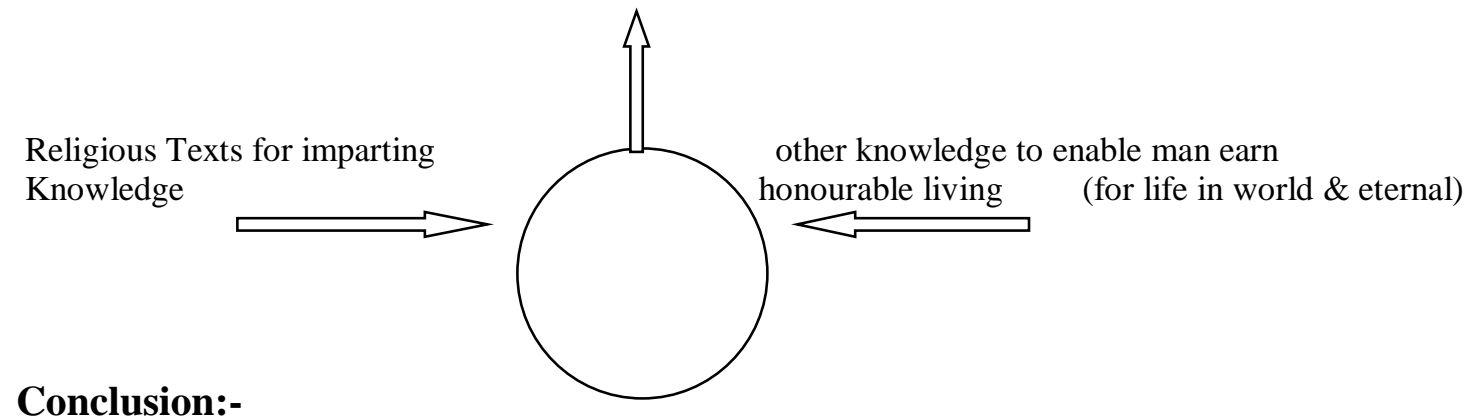

Conclusion:-

Islam has, from its inception, placed a high premium on education and has enjoyed a long and rich intellectual tradition. Knowledge ('ilm) occupies a significant position within Islam, as evidenced by the Qur'an. The importance of education is repeatedly emphasized in the Qur'an with frequent injunctions, such as "God will exalt those of you who believe and those who have knowledge to high degrees" (58:11), "O my Lord! Increase me in knowledge" (20:114) and "As God has taught him, so let him write" (2:282). ${ }^{90}$ Such verses provide a forceful stimulus for the Islamic community to strive for education and learning.

There is a very close relationship between morality, religion and education, such that we found out morality is being controlled by knowledge (education) and also religion influences it. For an individual to be regarded as a religious righteous person moral is essential and one cannot practice what is not known to him hence, knowledge is also important.

Muslims in Kenya have been having complexity in terms of designing a proper course which could cut across all the aspects of life. This involves putting equal emphasis in all forms of knowledge to acquire a well balance system. This is evidenced by the development of Madrasas, IRE in schools to IIEP schools.

${ }^{90}$ Serdar A. “The Qur'an” (Turkey; Okyanus, English translation) pp.273, 158, 28 


\section{Chapter three \\ The establishment of Islamic integrated education programme and its role in moral and religious development of learners in Nairobi \\ Background of Islamic Integrated Education Programme in Nairobi}

The IIEP was initiated by the Muslim community in Nairobi; this was as a result of trying to find a solution to dualistic system of education. The children were forced to attend to both formal and Madrasa education at different settings and time. Some parents felt that religious knowledge is best imparted at tender age therefore took their preschool aged children to Madrasa instead of formal education. The pioneer IIEP schools in Nairobi started as Madrasas, offering religious knowledge in the evenings. There were a few students who attended during the day. Due to the availability of facilities like classrooms which were vacant during the day, the Muslim educationists and community saw the need to provide formal education. ${ }^{91}$ The idea was implemented and formal trained teachers were employed while Madrasa teachers were employed on part-time basis. Madrasa teachers were given specific time during the day for the lesson. Later, the need to employ full time qualified Madrasa teachers became evident. With the absorption of Madrasa teachers fully into the system led to integration of the Madrasa and formal lessons. This has not been fully adopted in secondary schools due to the nature of curriculum and time allocation. Initially much of the financing come from the community, although now most schools rely much on fees collected. ${ }^{92}$

In Nairobi IIEP schools are all privately owned and managed. 99\% of these schools are located in their catchment areas where majority of the residents is Muslim. $99 \%$ of the students are Muslims. In day schools like Maina Wanjigi secondary, we found out that $98 \%$ of the students reside from within or the environs. Whereas in boarding schools the number is half by half, since other students come from other places in Kenya. The small number of non - Muslims (6.9\%) in Muslim Academy are not forced to follow the IIEP curriculum.

Table 1:-Showing the schools studied and the number of Muslim students.

\begin{tabular}{|l|l|l|l|l|}
\hline School & $\begin{array}{l}\text { Area } \\
\text { in Nairobi }\end{array}$ & $\begin{array}{l}\text { Number Of Of } \\
\text { Muslim students }\end{array}$ & $\begin{array}{l}\text { Number } \\
\text { students Of } \\
\text { other religions } \\
\text { from }\end{array}$ & $\begin{array}{l}\text { Number } \\
\text { students } \\
\text { given } \\
\text { questionnaire }\end{array}$ \\
\hline $\begin{array}{l}\text { WAMY High } \\
\text { School South B }\end{array}$ & 436 & 1 & 10 \\
\hline $\begin{array}{l}\text { Rasul-Al Akram } \\
\text { Girls' Pecondary } \\
\text { school }\end{array}$ & Park Road & 148 & 0 & 10 \\
\hline $\begin{array}{l}\text { Muslim Academy } \\
\text { Boys } \\
\text { Girls }\end{array}$ & Park Road & 143 & 0 & 10 \\
\hline $\begin{array}{l}\text { Maina Wanjigi } \\
\text { Secondary school }\end{array}$ & Eastleigh & 242 & 18 & 10 \\
\hline $\begin{array}{l}\text { TOTAL } \\
\text { Park Road }\end{array}$ & 132 & 468 & 10 \\
\hline
\end{tabular}

The Islamic Integrated Education Programme Curriculum

The curriculum of IIEP is primarily directed from young children to adolescents, beginning as early as age three, and is centred on Qur'anic and Hadith studies and on religious obligations and practices such as ritual ablutions, fasting, and prayer. Two schools, Rasul Akram and Muslim Academy also focus on the early history of Islam (Tareekhul- Al Islam), on the education of youth it reflects the belief that raising children with correct principles was a holy obligation for parents and society. There were some differences noted among the Sunni and Shia Muslim schools in religious beliefs (Aqeeda). Aqeedah (Islamic theology) encompasses the fundamental beliefs in a particular Muslim sect. We were able to find out that, there are different sects of the Muslim students in Rasul Al

${ }^{91}$ Muslim manager and educationist in Nairobi. On $25^{\text {th }}$ Nov, 2011

${ }^{92}$ Fatma. A. Saman, Principal Nairobi Muslim Academy. On $25^{\text {th }}$ Nov, 2011 
Akram School; out of 148 students 116 are of Sunni sect (78.4\%) as opposed to other IIEP schools where the proprietors are Sunni Muslims and majority of students are also Sunni. There was no compulsion in holding the beliefs as noted in this Shia school.

Memorization and learning of the Qur'an recitation is central to the curriculum in all IIEP schools. Though it was found that little attempt is made to analyze and discuss the meaning of the text. Arabic language is used during the recitation of Qur'an where 88\% of the students in all the IIEP schools do not understand the language. Out of 20 IIEP teachers interviewed all argued that, they teach the Qur'an to enable the learners perform accordingly the religious duties as required. There is a lot of emphasis on application of the verses of the Qur'an and also Hadith enabling the students to get to understand what they read. Out of 969 Muslim students in IIEP schools only 126 students (13\%) study Arabic as a language, which is examined by the M.O.E as a foreign language.

Fiqh (jurisprudence) is a subject which is taught in a few IIEP schools, we found it being taught in Muslim Academy and Rasul al Akram. It is mainly concerned with Islamic legal system, and the students are exposed to common actions relevant to their levels and Islamic legal code regarding them for instance in relationships, worship, rights, and so on. The main problem here is that, the curriculum being Hanafi or Shiite does not benefit much the students and causes a lot of confusion especially to the students with a firm religious background.

Islamic ethical code is highly emphasized like interaction between male and female students are restricted, dressing code, greetings among others. This is taught in all of the IIEP schools, the subject is known as tarbiya/ akhlaq (mannerism / morality). Although this subject is not reflected in IIEP schools timetables (Appendix VII). The aim is to enable Muslim youth be able to acquire Islamic principles of ethics and fit in the Muslim community in the future. We can therefore conclude that, there is no harmonised curriculum as such and the curriculum was determined by the management of the schools based on sectarianism. The IIEP curriculum has not been harmonized. In the Islamic schools investigated there were some commonalities and also sharp differences in different schools for instance in Muslim Academy they use the South African curriculum called 'Jamiat Ulama Taalimi Board' from Transvaal, IIEP teachers in the school argue that the curriculum is based on Hanafi school of Islamic law, while the Kenyan IRE curriculum is based on Maliki school. Although both schools are of Sunni sect, still there are some slight differences.

Table 2:-Shows the curriculum offers the following subject areas;

\begin{tabular}{|l|l|l|l|l|l|l|l|}
\hline \multicolumn{7}{|c|}{} & \multicolumn{7}{c|}{$\begin{array}{c}\text { CURRICULUM } \\
\text { (Subject areas) }\end{array}$} \\
\hline School & $\begin{array}{l}\text { Muslim } \\
\text { Sect }\end{array}$ & Qur'an & Hadith & Fiqh & Aqeedah & Tareekh & Akhlaq \\
\hline WAMY High & Sunni & $\sqrt{ }$ & $\sqrt{ }$ & $\times$ & $\times$ & $\times$ & $\sqrt{ }$ \\
\hline $\begin{array}{l}\text { Rasul-Al Akram } \\
\text { Girls'school }\end{array}$ & Shia & $\sqrt{ }$ & $\sqrt{ }$ & $\sqrt{ }$ & $\sqrt{ }$ & $\sqrt{ }$ & $\sqrt{ }$ \\
\hline $\begin{array}{l}\text { Muslim } \\
\begin{array}{l}\text { Academy,Boys \& } \\
\text { Girls }\end{array}\end{array}$ & Sunni & $\sqrt{ }$ & $\sqrt{ }$ & $\sqrt{ }$ & $\sqrt{ }$ & $\sqrt{ }$ & $\sqrt{ }$ \\
\hline $\begin{array}{l}\text { Maina Wanjigi } \\
\text { Secondary }\end{array}$ & Public & IRE & IRE & IRE & IRE & IRE & IRE \\
\hline
\end{tabular}

\section{Background information of Teachers}

The total number of IIEP teachers interviewed was 20, while other teachers in IIEP schools were 30 . We were able to find out that out of the 20 teachers 5 are graduates from South Africa, Islamic University of Sudan and Iran, others are locally trained in Islamic Institutes and Madrasas. 4 graduate teachers have attained the Form level of education except one who is a class 8 leaver. The other 15 teachers have varied education level $91 \%$ being class 8 leavers while the remaining portion have attained Madrasa education only. 
Figure 4a) \& b):-Showing IIEP teachers' academic background Level of Islamic education

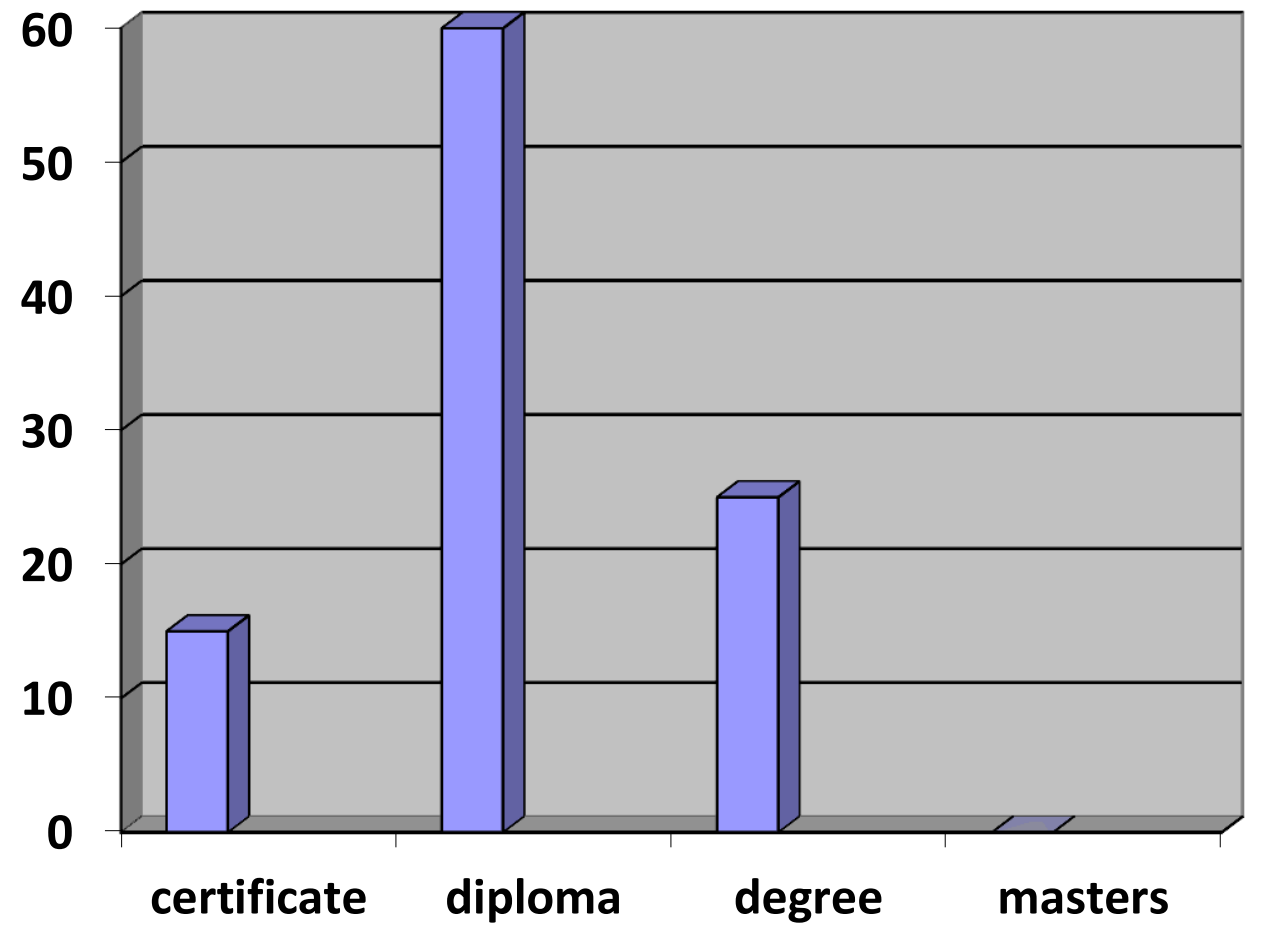

\section{Level of formal education}

Religious education qualifications

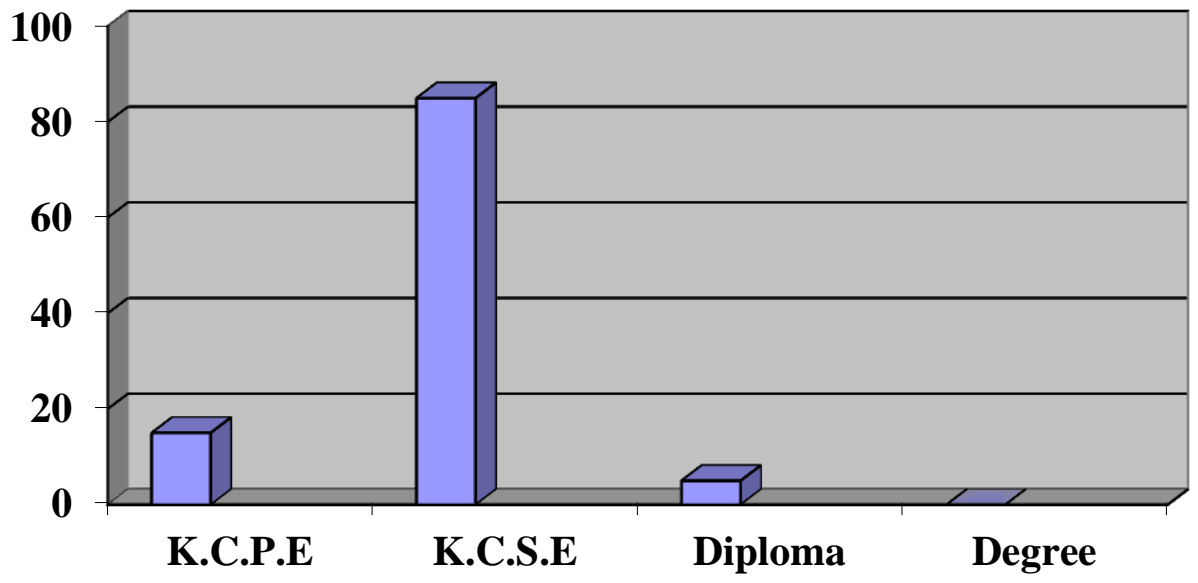

\section{Formal education qualifications}

All IIEP teachers interviewed were only 20; their number was smaller compared to other teachers (50), teacher respondents in the IIEP schools with a percentage of $26.7 \% .98 \%$ of the total number of the teachers' respondents (50) complained about low remunerations. $90 \%$ of the teachers in IIEP day schools complained about the heavy work load, since the students have to cover and acquire all the intended objectives set by the government and the school, teachers are given a lot of lessons in a week (between 28 - 38). One of the heads of IIEP department gave reason that, the school needs to cut down on expenses in order to cater for the teachers' salaries and other expenses, therefore cannot afford to employ many teachers since they are operating a double system. 
In WAMY High school there are two teachers in charge of IIEP one handles Qur'an while the other deals with other subjects taught as indicated earlier. Due to the number of students it is difficult for the teachers to cater for individual problem in the recitation of Qur'an. There is no assessment given to the learners as such therefore some students do not attend the Qur'an lessons. In other schools like Muslim Academy and Rasul Al Akram, there is an assessment given to the learners at the end of each term based on the curriculum offered. In Muslim Academy, at the end of two years the students are given a final examination and awarded certificate from South Africa in Muslim Academy. The problem here is that the school admits students anytime therefore it becomes a problem for the teachers and also students to catch with the system when admitted in form two classes.

\section{Moral and Religious role of IIEP}

Education in Islam is twofold: acquiring intellectual knowledge (through the application of reason and logic) and developing spiritual knowledge (derived from divine revelation and spiritual experience). According to the worldview of Islam, provision in education must be made equally for both. Acquiring knowledge in Islam is not intended as an end but as a means to stimulate a more elevated moral and spiritual consciousness, leading to faith and righteous action. Quraishi (1983, p.4) says, '...true knowledge helps the soul to make itself loose from its attachment to people, its devotion to the lusts and vanities of this world, its craving for power and glory, its exposedness to the temptation of envy and enmity, its unscrupulousness in the struggle for existence and its reliance on skills or wealth rather than on the Lord'.

We found out that, knowledge in Islam acts as a bridge for one to attain happiness in this world and the hereafter, and to become close to God. Knowledge related to both the spiritual and physical aspects of the human is important to acquire, and it should enlighten the heart towards good character between the human and His creation in this world. Humans should act as the instrument of the Divine and surrender to God's will. Thus, knowledge in Islam does not neglect the importance of social community and responsibility to the state. Knowledge is also able to increase the sincerity of worshipping Allah the Almighty, which results in a person becoming more pious towards Him. 99\% of the IIEP schools which have succeeded in this, observe and enforce the tenets of religion, are boarding schools, and they play the role of the parents in nurturing morality and religious values.

All the 20 parents interviewed agreed that they brought their children to IIEP schools because of spiritual and moral issues. They strongly hold the belief that religion plays a big role in maintaining order in the society. In the IIEP schools investigated there is no lesson indicated as Akhlaq (moral lesson) the teachers argued that normally it comes in between the other subjects they teach and especially Fiqh (Jurisprudence). Morality is also taught largely informally through religious lectures during weekends, morning assemblies, Islamic rallies, talks, among others. ${ }^{93}$ The IIEP is believed by the parents to be an instrument where children can acquire their religious values, moral and practice of religious activities freely. ${ }^{94} 85 \%$ parents and community still feel that much has been left out in terms of achieving this noble objective.

A Muslim educationist holds the belief that, in order for development of moral and practice of religious duties then parents also must take their responsibility in enforcing the same. ${ }^{95}$ Most of the parents neglect their responsibility of enforcing good morals and even commanding what is good in children. In day school investigated, being a secular government school (which offers IRE subject to the Muslim students) students' morality depended largely on the home background. In order to impart religious values the parents and teachers should work together to ensure that they insist the same, sometimes schools insists on religious practices like prayers and students perform them but when they go home nobody follows up, therefore they just perform those duties while in school environment only. Some parents are also not good role models to their children like wearing hijab is compulsory in IIEP schools, but you find their parents come to school indecently dressed, all these drains the efforts of teachers. ${ }^{96}$ The secondary school level is very challenging and most of them want to explore and experience a lot, due to advancement of technologies and globalisation it has not been easy to manage the teens. ${ }^{97}$

\footnotetext{
${ }^{93}$ Moral Education teacher, WAMY High school, $16^{\text {th }}$ Feb, 2012.

94 A parent with a daughter in IIEP School, interviewed $23^{\text {rd }}$ Nov, 2011.

${ }^{95}$ Muslim respondet Interviwed $7^{\text {th }}$ March, 2012.

${ }^{96}$ Muslim lady respondent. IIEP teacher, $20^{\text {th }}$ July, 2011.

${ }^{97}$ Respondent, parent with a child in IIEP secondary school.
} 
According to the findings the IIEP stakeholders and the Muslim community at large hold the same belief that religious duties and morality is important in Islamic Integrated schools. Parents and the community at large should take responsibility in supporting the system to achieve its objective in moral and religious development of the learners.

Figure 5:-Shows the outcome of education in IIEP schools

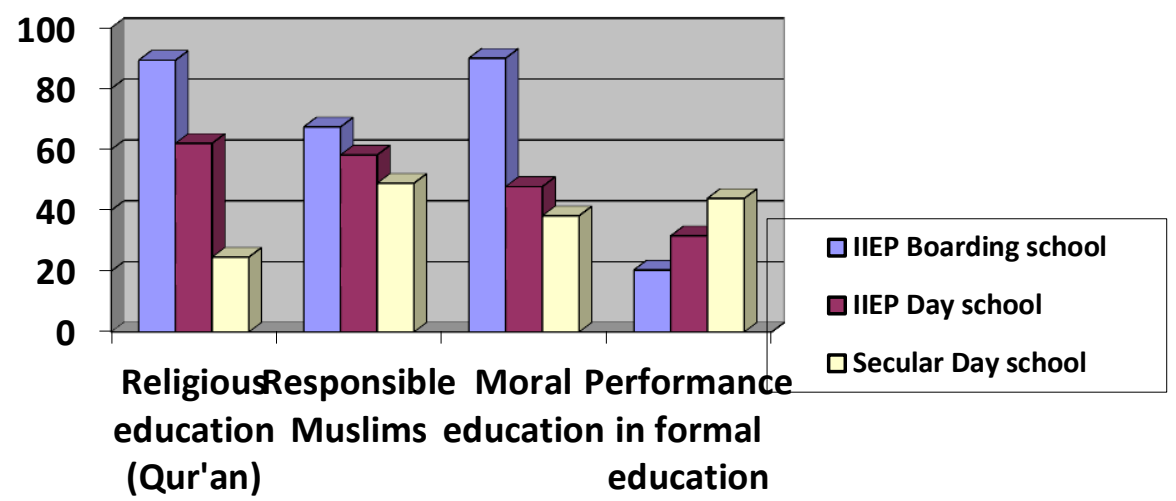

\section{Mandate and Purpose of Islamic Integrated Education Programme in Nairobi}

The main purpose of IIEP in Nairobi is to operate on the ideal of producing all-rounded Muslim citizens who respect others, work diligently and honestly, and serve as examples within their families and communities at large. ${ }^{98}$ They aspire to produce good Muslims who are morally upright who can well in this world with required competences, while upholding Islamic principles and values. ${ }^{99}$

According to the brochures from the IIEP schools investigated, we can therefore deduce that the following as the mandates undertaken by the schools in Nairobi County;

1. Strengthen the practice and internalization of Islam.

2. Provide knowledge, skills and moral values.

3. Incorporate the MOEST educational values.

4. Match learner ability and interest with the appropriate education.

5. Cultivate basic skills required for progress in the society

6. Produce learners who are more determined to face the contemporary challenges of modernity.

7. Provide human resource training that contributes national initiatives and efforts towards human research and development.

8. Establish a well-defined format for assessment and measurement.

9. Increase achievement levels in literacy, numeracy, scientific literacy and functional literacy.

10. Give due emphasis to individual's differences among learners in terms of academic achievement.

11. Promote co-curricular and extra-curricular activities in order to release their potentials.

\section{Evaluation of the Mandates}

We were able to gather information on the success and failures of IIEP in fulfilling its mandate, through the questionnaires given to the teachers, interviews with some parents and other stakeholders of IIEP schools. The responses provided were categorised as strengths and threats. This provides an evaluation of the mandates of IIEP, assessing whether the objectives intended have been achieved so far.

\footnotetext{
${ }^{98}$ A sheikh and teacher in IIEP school, interviewed on $20^{\text {th }}$ July 2011.

${ }^{99}$ Respondent, a Sheikh.
} 


\section{Strengths}

The IIEP since its inception was highly regarded by Muslims since it came as a solution to the dilemma which parents were facing. This is because the perception of the Muslims was very positive, and this strengthens the system. Some of the strengths of the system identified were;

It affords students a rich opportunity to study their religious knowledge on a broad perspective. This is made easy due to availability of time, rather there is no time wasted to go to a different setting to attend Madrasa. Due to the nature of IIEP schools it is easier for the students to practice Islam without restrictions, therefore learning becomes more practical.

Due to the combination of two systems there is unity of knowledge, this makes the students to perceive religious education (Madrasa) is as important as formal education. The combination also brings about mutual understanding, cooperation, unity, social interaction and even religious tolerance among staff from the two different systems. During the interviews with teachers in IIEP schools one of the Christian teacher commented that, he had never known much about Islam but being in IIEP school has removed some of the misconceptions he had before.

The system has also relieved the parents of the burden in terms of organising for Madrasa tutors for their children after school. Through the interview with schools principals and some parents we were able to gather that, $90 \%$ of the IIEP parents are cooperative and readily available. Parents have realized the importance of religion in the society in shaping the lives of their children; they therefore support the IIEP schools. One parent from Canada commented that, the main reason why he had to relocate was to ensure that his children get religious and moral education here in Kenya and got the IIEP school.

Availability of resources is also important in achieving the knowledge, skills and attitude intended. The IIEP schools visited have rich facilities which can enhance quality learning both religious and secular. Some of the facilities identified were, prayer halls, mosques, ablution facilities, IT department, cyber (E-learning), counselling department, well equipped laboratories, library and some had spacious playground with outdoor play facilities and spacious classrooms.

A few staff showed some extra commitment to the pupils, through monitoring even their non-class activities, offering counselling services without extra pay. Teaching Qur'an individual students during free time, and other secular lessons.

There is awareness and close working relationship with the government education bodies such as MOE, KNEC, PDE, and KIE. This is evidenced by several workshops carried out in two IIEP schools which involved two weeks training of all teachers on curriculum, examinations, instructional resource among others. There has been good performance in a few schools such as WAMY High which was top three in the country among private schools in 2011 National Examinations.

\section{Threats}

There are some weaknesses found in IIEP schools, these were found through observations, parents, teachers and students responses. These threats were summarised as follows;

Failure to retain teachers which in turn may lead to parents losing confidence in the schools. This failure as identified earlier is resulting from poor salaries for the teachers, heavy workload and also availability of many private schools as manifested in Nairobi currently. The cost of living is high for the people working in Nairobi therefore teachers are not stable in their jobs and always on the look for better opportunities (greener pastures) Poor management bodies that come up with poor school policies. One of the senior teacher respondent said that, the members of the school's committee body has no expert in education, most of the members are business entrepreneurs. This is a problem, because most times the school becomes a business enterprise forgetting the mandates for its establishment.

Lack of self drive and team work in some schools. The research revealed that the IIEP schools which perform badly, the teachers also lack self drive which makes learners to withdraw. This attitude among teachers is as a result of poor working conditions, uncooperative and unsupportive management, low remuneration and school policies. Lack of ownership reduces dedication. 
There is no established well-defined format for assessment and measurement. There is no monitoring system in IIEP schools and the two schools which assess students in IIEP do not have a systematic organized way. IIEP learning is largely informal and therefore accountability is rare. There is no harmonised curriculum or a curriculum which is not applicable to learners; therefore the content taught to the learners could be irrelevant if not applicable. Learners are promoted to the next level regardless of poor performance in IIEP.

IIEP is in a stiff competition with secular education, which is promising a brighter future. This competition has resulted in loss of focus of the religious mandates and possible ways to improve the programme. Rather more focus is given to secular education.

\section{Conclusion:-}

The establishment of IIEP towards achieving moral and religious development of learners in selected schools in Nairobi is widely controlled by the religious curriculum offered in IIEP schools. The diversity of Islam as a religion into sects is an evident hindrance factor towards achieving some goals and a harmonised curriculum. It is through the curriculum of these schools that we get to understand the schools' character and vision. The school environment and curriculum plays a major role in shaping the moral and religious development of the youth. IIEP boarding schools in Nairobi plays a significant role in moral and religious development of learners; this can mainly be attributed to availability of time to concentrate on both systems of education. The home background/upbringing also has a significant effect on moral and religious development apart from the school.

There are several strengths and threats after evaluation in IIEP mandates. The threats could be seen slightly fewer but the effects are greater than the strengths. This could be one of the reasons for variety of attitude towards the system in fulfilling its mandates.

\section{Chapter four \\ Factors that hinder the achieviement of Islamic integrated education programme's goals Introduction}

We identified several factors which affect the IIEP system of education in secondary schools. According to the data from the field some of these factors are internal, meaning that, the result from the nature of the system itself and others are external which results from factors from external influences (outside the system). These factors are;

\section{Division in Knowledge}

The IIEP system runs on the basis of the classification of knowledge into "religious knowledge" and "secular knowledge". These two types of knowledge are totally alien to each other, run in separate ways with their own separate systems of education.

Religion is no longer treated as relevant to society and world affairs, it is solely focused on the purification of the soul, understanding the Holy Qur'ān and Sunnah, and concentrate only on the life of the hereafter, whilst the secular knowledge or system of education only concentrates on the world's knowledge without relating it with religious values.

Religion is only treated as daily common rituals, and does not have any relation to daily life or work. Thus, a dualistic style of life exists and it is the task of education to harmonize the worldly and religious matters towards a perfect Muslim identity.

This division has further led to all IIEP schools to focus more on secular academic performance in national examinations (K.C.S.E) rather than religion. This shift of focus is also contributed by perception of the community that IIEP schools are not performing in formal education and withdrawal of children from the schools. The IIEP has therefore double responsibility to ensure excellence in all the two system implemented. This requires proper designs, appropriate manpower (quality and quantity), infrastructure among others, and all these require proper funding.

\section{Secularization and High Cost of living}

Secular education is more popular in society because it promises or provides better job, salary and life later to the students. If a leaner performs very well in secondary secular education, she/he has the opportunity to take a good and well paying career course which promises a better future. All parents want their children to get better careers that would enable them get a good job, better salary and good life. Most parents, whose children have performed very well in primary schools, prefer to send them to national secular schools, which have a record of excellent 
results in order for their children to pursue better careers in future. This will enable them to get good jobs or government positions in the future.

According to Shorter, "secularism is the situation in which religion loses its hold both at the level of social institutions and at the level of human consciousness." ${ }^{100}$ Secularism puts a lot of emphasis on economic factors and down plays human motives and character and reduces one almost to a scientific object. ${ }^{101}$

Due to the effects of secularism and high cost of living especially in cities like Nairobi, out of the 20 parents interviewed (16) $80 \%$ of the Muslim community are also concerned about secular education performance as to religious education.

\section{Lack of Sufficient Qualified Manpower}

In some schools students tend to memorize volumes of notes and textbook pages; they often lack competence in critical analysis and independent thinking.

Another major concern is the rapidly crumbling system and environment of moral training in some of IIEP schools. In some of these schools, there is no system worth the name IIEP for students' intellectual, religious and moral training and nurturing. This is due to lack of qualified expertise to handle both psychological with morality issues bringing in the religious element of it. The IIEP schools need experts who are capable of addressing the changes in the society and equip students with relevant skills enable to adapt to the contemporary issues. As indicated earlier, only $25 \%$ of the teachers have attained teachers' training courses and qualifications. Therefore the problem of applying appropriate teaching methodologies is evident.

There is also a shortage of Arabic teachers and mostly the teachers who understand the language do not have formal education, they are Madrasa oriented without formal education. Hence they lack the proper expertise on how handle the students and the subject itself.

\section{Low Remuneration}

The salaries and other benefits given to the IIEP teachers and other secular teachers are insufficient and their employment is not secure. This is why as soon as avenues for government employment are opened to them; many graduates and experienced teachers (formal non- IIEP teachers) choose that option. This affects the performance of the students especially in national examinations. This is another serious issue that needs to be properly addressed.

The IIEP schools have dualistic system which forces them to employ more teachers compared to other schools, and the school fees sometimes are slightly higher for middle class Muslim parents. They therefore opt for the cheapest education for their children, making only a few Muslims who are capable to access IIEP system of education.

\section{Poor Consultation and Coordination Mechanisms}

The issue of consultation and coordination is not much; each IIEP school works independently under a management body of Muslim individuals. There is one which has been formed in Nairobi known as 'Muslim Education Council' where stakeholders manage different IIEP schools, but the fact is that there is hardly any co- consultation among the schools and each work independently based on sectarianism. It is evident that there are different projects designed but there is little so far which has been done like employing IRE part-time teachers in some public schools and paying them. Different proposals have been laid but the main problem is finance, where the major source is donations. ${ }^{102}$ There is no overseeing authority that can check and regulate their finances and functioning, these being entirely in the hands of a single individual or a small group of selected persons. Among these institutions are many that better deserve to be called 'religious shops' rather than religious schools, for their financial irregularities are serious and continue to increase. There is an urgent need to involve the Muslim community and creating awareness, select qualified and skilled people to run the affairs of bodies formed to look into Ummah's issues. This can be better achieved through eradication of biasness and prejudices in such institutions. As God says in the Qur'an,

\footnotetext{
${ }^{100}$ Shorter Alyward, in -Secularism and Emerging Religious Movements- Mugambi J.N.K \& Getui M.N , (edts)," Religions in Eastern Africa under Globalization”( Nairobi; Acton Publishers, 2004)p.253

101 Ibid; p. 254

${ }^{102}$ Respondent, Muslim educationist, $7^{\text {th }}$ March, 2012.
} 
"Hold fast together to Allah's cord and let nothing separate you." (Q 3:103) ${ }^{103}$

\section{Poverty}

"The vast majority (up to 75\%) of the Africa city's inhabitants reside in the low income areas and more than half of these live below the official poverty line." ${ }^{\prime 04}$ Muslim community in Nairobi County, which is the capital city of Kenya are not spared of poverty.

Most Muslim parents appreciate the IIEP education but are not able to access due to financial constraints. This is why the programme cannot be fully embraced by the Muslim community. The schools proprietors argue that they charge 'reasonable fees' which according to $81 \%$ of the parents (respondents) said, they cannot afford the so called 'reasonable fees' by IIEP schools. The Muslim community also argues that the living conditions in Nairobi are escalating each day forcing them to opt for cheaper government schools or other private secular schools. "These schools are only meant for the few Muslims who are capable in our society and not everyone." 105

Due to the financial constraints most Muslim students are left out and only those who can afford access IIEP education. The IIEP schools can also not offer free education since their main source of generating income to pay teachers and running the schools' programmes come from school fees. 15\% of IIEP schools get some external aid in terms of buildings and infrastructure but this is normally inform of loans from organizations such as IDB ( Islamic Development Bank), WAMY among others. ${ }^{106}$

Sometimes this creates a negative perception on the side of the community, thinking that the IIEP receive donations and other forms of funding which goes to the individuals' pockets, rather than helping community. This kind of attitude is not as a result of poverty since some of these parents take their children to high cost schools compared to IIEP schools. ${ }^{107}$

\section{Efforts to expand outreach to Muslim community}

In all IIEP schools investigated we found out that $90 \%$ of the students are Somali. The programme does not seem to cut across varied Muslim ethnicity in Kenya so to speak. The other ethnic group parents zero down this situation in terms of finances. That IIEP schools design the fees looking at the Somali factor, which automatically locks them out of the system. ${ }^{108} 80 \%$ of the Somali parents at least have a reliable source of income some are refugees with relatives abroad who support them. $40 \%$ of the students in IIEP day school are foreigners who are undertaking the International system (IGCSE- British system), their fees is slightly higher than the local 8.4.4 system fees. This also has some effects on the language use in school. Due to the majority being of one ethnicity, the students frequently use their mother tongue.

Some Muslims have different perceptions about the system, and regard taking their children to Madrasa is enough. They think that the system leads to irrelevant career in the modern world. The IIEP efforts to reach all Muslim diversity has became an issue of concern since this to a large extent has contributed to the system not achieving its objectives in uplifting spiritual and moral aspects of Muslim youths

\section{Contextualization}

Contextualization is an approach of interpreting the Quran that requires consideration of the text as a whole, the position of verses within the text, the circumstances or conditions of the Prophet Muhammad and the early Muslim community at the time of the revelation, and the contemporary situation or issue for which the Quranic guidance is sought. ${ }^{109}$ The IIEP should develop a system where the students will be instructed on ways of interpreting Qur'anic verses in a simpler manner applicable in their day to day lives. During the observation we were able to identify that during Qur'anic lessons there is room to reflect on particular verses or a specific day/days to interpret the verses

${ }^{103}$ Serdar A. "The Qur'an” (Turkey; Okyanus, English translation) p.36

${ }^{104}$ Shorter Alyward, in -Secularism and Emerging Religious Movements- Mugambi J.N.K \& Getui M.N , (edts)," Religions in Eastern Africa under Globalization"( Nairobi; Acton Publishers, 2004)p.257

${ }^{105}$ Respondent, A Muslim parent in Majengo, Nairobi. Interviewed on $25^{\text {th }}$ Feb, 2012.

${ }^{106}$ Muslim respondent, Op.cit

${ }^{107}$ Muslim lady respondent an educationist. Op.cit

${ }^{108}$ Parent ; Muslim Academy, $23^{\text {rd }}$ Nov, 2011.

${ }^{109}$ Saeed, A, “Interpreting the Quran: Towards a Contemporary Approach." (London: Routledge 2006). p.8-10 
memorized. $99 \%$ of the students were memorizing Qur'an during the lessons while a few memorizers were teaching the other students Qur'an. One of the female Qur'an teachers said that the contextualization content is taught at a higher level. But the challenge here is that most of these students after secondary education focus on other fields apart from Islamic studies and mostly this is their final religious studies.

The approach actually originates with the companions of the Prophet but has been marginalized and even condemned by proponents of the more dominant textual approaches. ${ }^{110}$

Contextualization in the Qur'an is the "emphasis on the socio-historical context of the ethico-legal content of the Quran and of its subsequent interpretations" and support a reading of the Quran based on the "political, social, historical, cultural, and economic contexts in which the content was revealed, interpreted and applied" ${ }^{111}$ As opposed to 'textualization', which base its claim on an 'objective' understanding of the meaning of the Quran on "linguistic evidence and historical reports", contextualists find meaning to be subjective and based on differing time, places, and circumstances. ${ }^{112}$

According to Gichure, the reason why contextualization should be insisted is that, our contexts can be altered as our faith continues to develop. We can develop interpretations from within the old models or paradigms. ${ }^{113}$

Consequently, diversity in interpretation is to be expected with differing experiences, beliefs, prejudices, and values of different interpreters. Due to this we have found out that the curriculum of different IIEP schools are not harmonized as such, and possibility seem limited.

\section{Learners' Differences}

We found out that in all IIEP schools investigated in Nairobi, learners have vast differences in religious knowledge. This could be resulted from factors such as learners' academic background and even home/family background among others. 98\% of the students respondents had previously attended Madrasa education from previous IIEP primary schools, local Madrasa, home setting Madrasa or both Madrasa and IIEP schools.

About $10 \%$ of the total Muslim students have memorised the Qur'an prior to joining IIEP schools and at times the curriculum does not cater for them, which at times we found them teaching other students during Qur'an lessons. While $80 \%$ of the students are still learning the Qur'an while memorising at the same time, the remaining $10 \%$ are at a very low level of learning Qur'an (beginners) mainly because of their backgrounds.

$40 \%$ of the learners have discipline and moral issues, this we found out that is attributed to upbringing, home environment, lack of proper religious information, peer pressure, lack of proper counselling system, human nature among others.

$85 \%$ of the students have moderate religious practical knowledge while $10 \%$ have poor religious orientation and $5 \%$ have excellent information in religious practical knowledge.

\section{Negative Perception by Muslim Community}

The chief aims of the Integrated Education System are to solve the problem of dualist education, inculcate Islamic elements across the curriculum, and provide a holistic education that addresses the physical, spiritual, and emotional needs, through the delivery of both revealed and acquired knowledge. Unfortunately, the interview findings indicate that most of the respondents lack knowledge and understanding about these aims. The Muslim community seems to have limited information regarding IIEP mandates, their expectations are too high. Muslims think it is now the responsibility of IIEP schools to take full responsibility of Ummah and forget the place of society itself in Another cause is cultural factor related to social "trust". For ages, the Nairobi Muslim residents have given their full trust to the traditional religious institutions (Madrasas) in delivering religious knowledge. When IIEP schools were suddenly administered under the formal school system, this created anxiety and mistrust, since people believed that this system would not provide proper teaching of religious knowledge. Given the long history of the dual system,

\footnotetext{
${ }^{110}$ Ibid;pp. 55-56, 124.

111 Ibid; p. 3

112 Ibid; p. 103

113 Gichure, P. I, “Contextual Theology; Its Meaning, Scope and Urgency.” ( Nairobi: Catholic University of Eastern Africa, 2008) p.75
} 
people tend to think that religious knowledge should be delivered separation from scientific knowledge. Some people would be more confident about the delivery of knowledge through two separate systems, which is evident from the questionnaire and interview results, in which $49.6 \%$ of teachers viewed that the two different systems, which integrated revealed and acquired knowledge, were sufficient in developing a well-rounded individual who is not only knowledgeable, but is also faithful, pious, and has good moral character. 50.4\% feel that it burdens the system over burdens the learners such that they do not have time for recreational activities which are non-teacher guided.

Misunderstanding, confusion, and misconceptions about the new systems, particularly the "Integrated Education System", lead to failure in their implementation.

\section{Conclusion}

Poverty is a major challenge to the establishment of IIEP schools in Nairobi County. This has prevented the system in acquiring and giving equal opportunities to all Muslim children at secondary schools in Nairobi. It has limited the progress of the IIEP and the Muslim community at large.

The Muslim community needs to establish functional education boards, income generating projects in the schools so as to have different sources of income and form efficient networks and collaborations and work through strict principles of professionalism. The challenges identified are a great threat to the progress and establishment of IIEP in Nairobi County and Kenya at large.

\section{Chapter five}

Summary of the findings, conclusion and recommendations

\section{Summary}

The study has been able to find out that, the Muslims for a long have been having a crisis on which education they should adopt, as a result of historical education systems. This dilemma led to imbalance education among the Muslim youth in terms of moral and religious development. We have doctors, accountants, engineers and so on who are heartless, selfish, and corrupt without taqwa (fear of God) and this is what we call development. ${ }^{114}$ This among many other reasons led to the development of IIEP schools in Nairobi. The IIEP schools studied are fully established since some were already operating as Madrasa, while others formal schools with a few newly constructed. There is a good number of Muslim students, however majority are from a single ethnic community.

The curriculum of IIEP should be differentiating factor between IRE offered by the MOEST and Madrasa curriculum of IIEP. We found out that the IIEP curriculum resembles the old Madrasa curriculum but the teaching approaches are different. There is minimal memorisation in IIEP and it is limited to Qur'an recitation. Implementation of the curriculum is left to the IIEP teachers and there is no specific organized way to monitor the curriculum, hence largely informal. This problem can be attributed to IIEP teachers training. The curriculum varies from one school to another depending on the Muslim sect of the school's management board. Therefore, the curriculum is not harmonised even among schools which belong to the same Muslim sect.

Despite the disorganized curriculum in some schools IIEP has greatly influenced the religious and moral development of students. This has been made possible because of the conducive religious environment provided by IIEP schools. Moral development has been enhanced informally through different programmes designed for the students like religious rallies, talks, sermons and so on. Religious development is largely influenced by the rich religious environment and facilities provided. There was a significant difference between students in IIEP boarding schools in moral and religious development as compared to other students in IIEP day and public schools investigated.

We were able to identify several factors that hinder the achievements of IIEP in Nairobi. These factors included poverty, secularization, outreach to the Muslim community, low remuneration, perception by the stakeholders among other factors. These factors adversely affect the progress of IIEP in achieving its goals.

\section{Conclusion}

${ }^{114}$, Muslim respondent, an educationist Op.cit 
In the Islamic perspective, both revealed and acquired knowledge are equally important for the development of a holistic, well-rounded person, who is not only physically but also spiritually trained to be a good individual in society. The ultimate aim of education should be to become closer to Allah the Almighty through the purification of the soul by cultivating good moral character and values. This will create a pious individual who fulfils his/her responsibility as the vicegerent of Allah the Almighty in this world. As Khosrow B. puts it, from behaviourist perspective, that education means a regulation of an individual's surrounding forces such that it could lead to the formation of specific behaviour in him. In Islamic belief it is the regulation of an individual's surroundings such that he would have the opportunity to be able to recognize the right and wrong ideas, to choose the right ideas and act accordingly. ${ }^{115}$

IIEP as seen plays a significant role in shaping the youth. It is through the system of religious education that Muslims are able preserve Islamic cultural heritage and pass it on to the future generation. Schooling plays a significant role moulding the society into responsible individuals and this is achieved through the curriculum offered. The religious curriculum that will be able to shape the character of Muslim community the one that, youth can prosper both in this world and in the hereafter.

However there are challenges faced by IIEP towards accomplishing its role in moral and religious development of learners this challenges are both external and internal. The Muslim community needs to get rid of minor divisions and prejudices which crumble their system of education.

\section{Recommendations}

The study recommended the following in order to address the challenges facing IIEP in the implementation of moral and religious development of learners.

The IIEP boards of different sects can continue to maintain their separate status but they must form a common board or platform to deal with issues of common concern to all of them. If possible come up with a comprehensive harmonised curriculum for Islamic secondary schools.

IIEP schools should make proper arrangements for the religious, moral and spiritual training of their students and should inspire them with a missionary spirit. Even having moral lesson in the timetable allocated specific time, incorporating the modern changes in the world and training learners on how to deal with them.

The schools should adopt alternative methods of fund raising and income generating projects in financing education like buying properties and renting them, school lunch programme, school buses, etc. apart from school fees. This will address the salaries problem and reach out the poor in the community. The salaries of IIEP teachers and other teachers in general need to be improved, and quality should be stressed over quantity. IIEP Teachers should be trained by schools in teaching skills. Having enough income will enable the schools to employ qualified and enough manpower.

IIEP should seek to have their roles, achievements and contributions highlighted in the mass media, for which they need to adopt a proper and well planned media policy. Therefore, efforts should be made to create public awareness either through talks, distributing leaflets, or the print media.

All parties involved in the implementation of the system should commitment themselves to the success of the system. Parents and community at large need to embrace and support the system in different ways for instance, financially, trust, expertise, advisory, enrolling children among others.

\section{Bibliography:-}

1. AbuSulayman, A 1993, Translation by Yusuf Talal DeLorenzo.Crisis in the Muslim Mind. Herndon, Virginia. USA: The International Institute of Islamic Thought

2. Al-Attas, Syed Muhammad 1979, Preliminary Thought on the Nature of Knowledge and Definition and Aims of Education: In Aims and Objectives of Islamic Education. Jeddah: Hodder and Stroughton, King Abdulaziz University.

\footnotetext{
${ }^{115}$ Khosrow B," Islamic Education" (Tehran: Iran, Centre for Cultural and International Studies, Culture \& Islamic Relations Organization, 2001)
} 
3. Al Faruqi, R 1982, Islamization of Knowledge: General Principles and Workplan.Brentwood: Maryland. International Institute of Islamic Thought.

4. Ashraf, S. A. (1985) New Horizons in Muslim Education. London, United Kingdom: Hodder and Stoughton.

5. Bakari, M. and Yahya, S. (eds) 1995, Islam in Kenya. Proceedings of the National Seminar on Contemporary Islam in Kenya, Mombasa: MEWA Publications.

6. Barlett, K \& Evans, J 2008. The Madrasa Early Childhood Programme: 25 Years of Experience. (Report Published by Aga Khan Foundation)

7. Brenner, L 2001, Controlling Knowledge: Religion, Power and Schooling in a West African Muslim Society. Bloomington: Indiana University Press.

8. Cohen, R etal 1973, Psych City: A Simulated Community (An Integrated learning Experience in the Psychology of Community Participation) PegamonpressInc.Rushatters Bay: Sydney.

9. Court, D 1979 The Education System As a Response to Inequality

10. Hadimi, M et al 2001, Ethics of Islam, $3^{\text {rd }}$ edition. Wakf Ikhlas Publication.Istanbul: Turkey.

11. Hamidullah, M 1982, Introduction to Islam. Islamic Republic of Iran: Ansariyan Publication.

12. Kaplan, I 1976, Area Handbook for Kenya Secondary Education. United States.

13. Kheir, A $26^{\text {th }}-27^{\text {th }}$ Nov, 2006, Contemporary Challenges and FutureAspiration of Islamic Da'awah in Kenya. Presented at InternationalConference on Islam in Africa. International University of Africa, Khartoum: Sudan. (unpublished)

14. Khosrow, B 2001, Islamic Education. Tehran: Iran, Centre for Cultural and International Studies, Cultural \& Islamic Relations Organization.

15. Kinyanjui, K 1974, The Distribution of Educational Resources and opportunities inKenya.University of Nairobi: Institute of Development Studies, Discussion paper No.208.

16. Ministry of Education Science and Technology 2004, Development of Education inKenya. Nairobi: Kenya.

17. Mugambi, J 1996, Religion and Social Reconstruction of reality. InauguralLecture on $26^{\text {th }}$ September 1996. Nairobi: Kenya. University of Nairobi Press.

18. Mulusa, T 1988, Evaluating: Education and Community Development Programmes.Published by Deutsche stiftung Fur Internationale ent.Wicklu and College of Adult and Distance Education, University Of Nairobi: Kenya.

19. Manani, H $15^{\text {th }}-17^{\text {th }}$ Nov, 2007, Accelerated Learning: New Opportunities for Children at Risk seminar. A paper presented by Ag. Deputy Director Kenya Institute of Education. Addis Ababa: Ethiopia.

20. Ochieng, W 1990, Themes in Kenyan History. Nairobi: East African EducationalPublishers Ltd.

21. Pickering, W 1984, Durkheim's Sociology of Religion; Themes and Theories. London.

22. Routledge and Kegon Paul Publication.

23. Quraishi, M.A. (1983) Some Aspects of Muslim Education. Lahore: Universal Books.

24. Rahman, F. 1982, Islam \& Modernity: Transformation of an Intellectual Tradition. The University of Chicago, United States of America: The University of Chicago Press

25. Republic of Kenya, MOEST 2002, Secondary Education Syllabus. Volume Three. Nairobi.

26. Saeed, A 2006, Interpreting the Quran: Towards a Contemporary Approach, London: Routledge.

27. Schneider, L 1970, Sociological Approach to Religion. U.S.A: John Wiley andSons, Inc.

28. Smart, N \& Horder, D (edts) 1975, New Movements in Religious Education. London: Russel Street, Billing \& Sons Ltd, Great Britain.

29. Somekh, B \& Lewin, C (edts) 2005, Research Methods in the Social Sciences. New Delhi. India. Vistaar Publications.

30. Trimingham, S 1964, Islam in East Africa. London: Oxford University Press.

31. Umarudin, M 1962, The Ethical Philosophy of Al-Ghazzali. Muslim University, Aligarh: Pakistan.

32. Williams, B 2009, Doctors and Imams: Investigating the Integrated School in Mombasa, Kenya. Wake Forest University.

33. Otiende, J \& Sifuna, D 1992, An Introductory History of Education. Nairobi: Kenya. University of Nairobi publication.

34. Oded, Arye 2000, Islam and Plitics in Kenya. L. Rienner, Boulder.

35. Zeno, J 1996, The Pillars of Islam \& Iman. Dar - us - Salam Publications, Riyadh, Kingdom of Saudi Arabia.

36. Getui, M 1993, The Religious Aspects of Secondary School Life And their Effects on the Youths in Nairobi. Phd Thesis, Kenyatta University: Kenya.

37. Kahumbi, N 1992, Muslim Education in Kenya, with special Reference toMadrasa System in Nairobi. M.A Thesis. Kenyatta University, Kenya. 
38. Kindberg, M 2010, From Jesus and God to Muhammad and Allah, and backAgain - Kenyan Christian and Islamic Religious Education.

39. Bachelor degree thesis.

40. Alwy. A and Schech.S. (2004) Ethnic Inequalities in Educational Resources in Kenya.International Education Journal Vol.5, No.2. Centre for Development Studies, Flinders University.

41. Svennsson Jonas (2010) Divisions, Diversity and Educational Directives: IRE Teachers' Didactic Choices in Kisumu, Kenya. British Journal of Religious Education. Vol.32:3

42. Svennson Jonas (Oct, 2006) Have You All Got Your Copy Of The Qur'an? Rationalisation, Ritual and Role of God's Word in Kenyan Islamic Educational Setting. Tidsskrift for islamforskning, vol.1

43. Friday Bulletin - Nairobi, published by Jamia mosque.

44. $25^{\text {th }}$ Feb, 2011 Issue No. 408;

45. $8^{\text {th }}$ April, 2011 Issue No.414;

46. $27^{\text {th }}$ May, 2011 Issue No.421;

47. $14^{\text {th }}$ Oct, 2011 Issue No. 441 ;

48. $3^{\text {rd }} \mathrm{Feb}, 2012$ Issue No. 457.

49. Towards Understanding Islam -Edition 02> October, 2011

\section{Internet sources}

http://www.islaminAfrica.word press.com/ 2010/03...

http://www.tymagmch.Blogspot.com/

http://www.siena-antis.com/200/07/the Madrasa

http://www.islamwatch.org/../madrasa.htm

http://www.akdn.org/press-release.asp? ID=210.

http://www.ibe.unesco.org/links.htm

http://www.researchkenya.org

http://education.stateuniversity.com/page/722/kenya

http://www.education.go.ke

http://www.groundedtheoryonline.com

http://www.methods.manchester.ac.ke.uk

\section{APPENDICES}

APPENDIX I

Teachers' Questionnaire

Introduction: My name is Fatuma K. Mwatamu, a Master of Arts in Religious Studies student, University of Nairobi. The questionnaire is intended to assess the religious and moral role of Islamic Integrated Education Programme in Islamic secondary schools.

\section{Tick appropriately}

GENDER
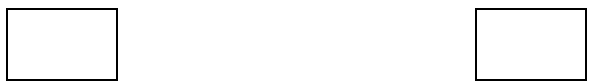

Male

Female

AGE

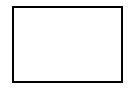

$20-$
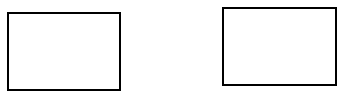

$25 y r s \quad 26-35 y r s \quad 36 y r s \&$ above

1. For how long have you been teaching in IIEP school/s?
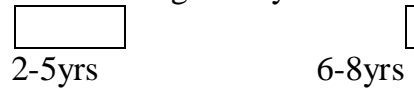

$9-15 \mathrm{yrs}$

$16 y r s \&$ above

2. Are you a professional trained teacher? 
3. What is your level of education?

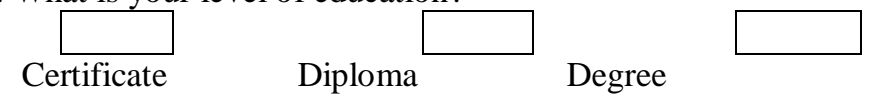

Any other

4. Do you have a specific curriculum for religious and moral (akhlaq) education in Madrasa in secondary schools?

Yes

No

5. The curriculum is from the:

Ministry of education/K.I.E

Old Madrasa

ANY OTHER BODY (specify)

6. a) Does it contain religious and moral(akhlaq) education?

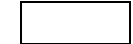

Yes

b) Is the moral and religious content adequate?

Yes

No

c) Explain your response above

d) What subjects are covered to address morality and religious concerns?

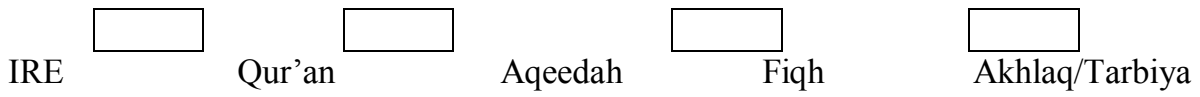

Any other specify

7.a) Do you encounter any challenges in IIEP system?

Yes

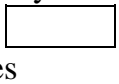

Explain your response above

No

b). What can be done to address those challenges?

8. Do you have programmes which IIEP use to impart religious and moral values in secondary school students?
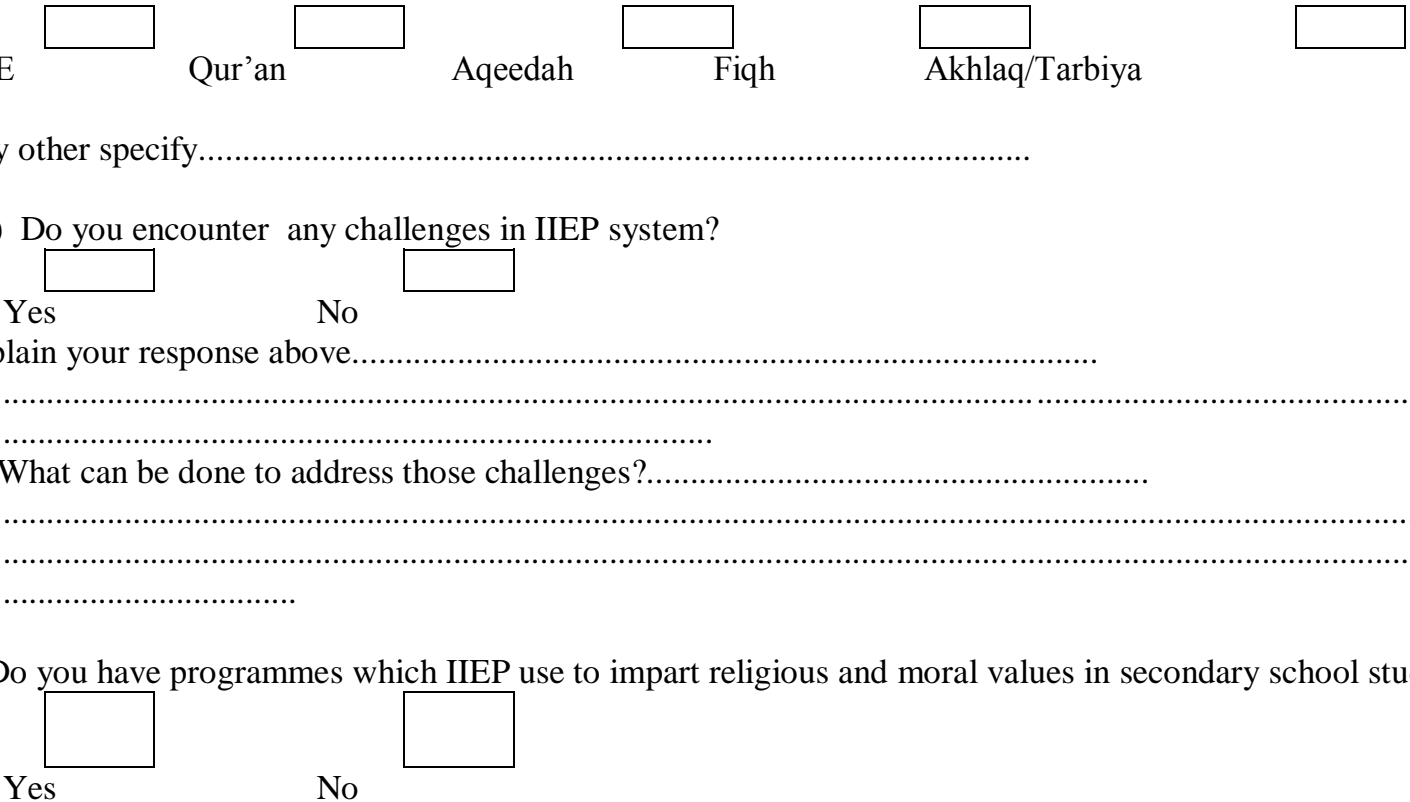

Akhlaq/Tarbiya

If yes mention some.

10. Do parents actively participate in school's religious activities?

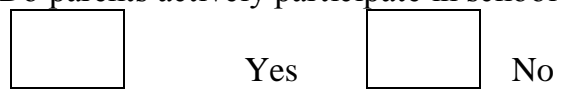


b) Explain your answer above

11. Do you teach sex education and awareness?

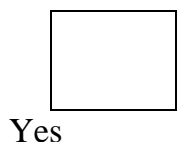

Yes No

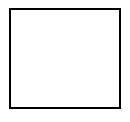

Explain your response

12. Are the following resources available to address moral and religious development of learners? Adequate Few Not available

a) Relevant reference books

b) Room/ hall for religious activities

c) Prayer mats

d) Mishaf / Qur'an

e) Interactive (audio-visual)

THANK YOU

APPENDIX II

Student Questionnaire

Introduction: My name is Fatuma K. Mwatamu, a Master of Arts in Religious Studies student, University of Nairobi. The questionnaire is intended to assess the religious and moral role of Islamic Integrated Education Programme in Islamic secondary schools.

\section{TICK APPROPRIATELY}

AGE
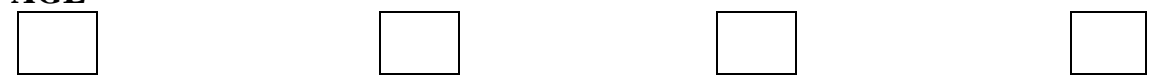

13-14yrs

$15-17 \mathrm{yrs}$

18-19yrs

20-23yrs

GENDER: Male

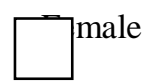

Name of school.

\section{EDUCATION BACKGROUND}

Tick the schooling you have been through

Nursery

IIEP

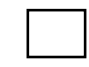

Government

Primary IIEP
Government
Private secular

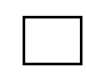

Private secular 


\section{CURRENT SCHOOL}

In general, what would you say about your school in imparting religious and moral values? (Circle one)

$\begin{array}{ll}\text { Excellent } & 1 \\ \text { V. good } & 2 \\ \text { Good } & 3 \\ \text { Fair } & 4 \\ \text { Poor } & 5\end{array}$

Do you like your school?

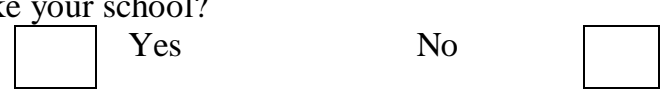

Explain your response above.

CURRICULUM COVERAGE (Circle one)

1. Is the content the same as that of Madrasa? $\quad \frac{\text { No }}{1} \quad \frac{\text { Little }}{2} \quad \frac{\text { A lot }}{3} \quad \frac{\text { All areas }}{4}$

2. Does the content interfere with your general performance $\{$ work load $\}$ ?

$\begin{array}{llll}1 & 2 & 3 & 4\end{array}$

3. Is the content of Islamic studies similar to IRE syllabus?

1

2

3

4

What are the challenges that you face in your school in terms of religious and moral development?

a) Is the issue of sexuality / sex education adequately addressed in your school?

Yes $\square$ No

b) Explain your response above

How do you respond to the following situations (tick where necessary)

\begin{tabular}{|l|l|l|l|}
\hline & Never & Frequently & Sometimes \\
\hline
\end{tabular}




\begin{tabular}{|l|l|l|l|}
\hline Cheating/ lying & & & \\
\hline Fighting / quarrelling & & & \\
\hline Sharing items & & & \\
\hline Do you solve your problems on your own? & & & \\
\hline Can you openly speak about sexual issues & & & \\
\hline $\begin{array}{l}\text { Would you respond when you see someone } \\
\text { doing wrong? }\end{array}$ & & & \\
\hline Girl/ boyfriend relationship & & & \\
\hline
\end{tabular}

Thank you

APPENDIX III

INTERVIEW GUIDE: (For Imams/ Religious leaders, School proprietors/principals and management body)

What position do you hold in the school?

What is the mission and vision of this school?

What differentiates it from public and private non- religious based schools?

Curriculum/ religious element/ ideals/ philosophy/ contributions...

Are there sufficient teachers with relevant qualifications?

Government/ public/ private colleges\& universities/ Islamic based institutes

Are graduates from IIEP able to transit well in to mainstream institutes (public universities, colleges and other tertiary institutes)?

What is the general public perception of IIEP?

MOEST/ parents/ government/ Muslim ummah

Is there future for IIEP in Nairobi and Kenya in general?

APPENDIX IV:

Syllabus Islamic Religious Education

\section{KENYA SECONDARY SCHOOL ISLAMIC \\ RELIGIOUS EDUCATION CURRICULUM \\ INTRODUCTION}

In the name of Allah the most

Gracious most merciful

Praise be to Allah, the Lord of the worlds, salutation and blessing be upon The Prophet (p.b.u.h)

The Secondary Islamic Religious Education (IRE) is aimed at exposing the learner to the fundamental principles and teachings of Islam. Islam is not merely a set of beliefs or rituals but a way of life. This syllabus is therefore designed to nurture the spiritual, moral, social, emotional and physical well being of the learner.

The syllabus consists 8 main areas of study, namely: -

1. Quran

2. Hadith

3. Devotional Acts

4. Pillars of Iman (faith)

5. Akhlaq (morals)

6. Muamalat (relationship) 
7. History of Islam

8. Muslim scholars

In this syllabus areas have gradually been based on what is taught in the primary I.R.E syllabus in a spiral approach. They are further divided into topics and sub-topics but they should be presented in an integrated approach. The syllabus is geared towards adaptability and appropriateness of the needs and interests of the students. Therefore it is highly recommended that the teacher employs life approach as a means of achieving the desired objective(s). The learning of IRE in secondary schools is geared towards enabling the learner face the challenges of life. Thus, special attention has been given to relating the teachings of Islam to issues such as HIV/AIDS, gender, child abuse, child labour and neglect, drugs and substance. Ultimately the syllabus aims at making the learners be at peace with his creator, self, others, and the environment

\section{General Objectives}

By the end of the course, the learner should be able to: -

1. acquire knowledge, values and principles of Islam

2. 2. Emulate the teachings of the prophet (p.b.u.h)

3. Appreciate and observe the fundamental beliefs and practices of Islam

4. Discharge his/her role and responsibility effectively as Allah's vicegerent on earth

5. Appreciate the wonders of Allah's creation and develop a sense of responsibility in managing the environment

6. Recognize work as a form of lbadah

7. Acquire relevant skills and values to cope with issues and challenges

8. Develop respect for and foster harmonious coexistence with other people through tolerance

9. Promote international consciousness through an understanding of the universality of Allah and equality of mankind

10. Appreciate the role of Islamic history in the development of human culture and civilization

11. Acquaint him/herself with the works and contributions of Muslim scholars and reforms.

\section{Form One}

1.00 Quran

\section{Specific Objectives}

By the end of the topic, the learner should be able to:

a) State the meaning of the Qur'an

b) Discuss the need for revelation of the Qur'an

c) Explain the importance of the Qur'an

d) Describe the role played by anger Jibril in the revelation of the Qur'an

e) Explain the reasons for revelation of the Qur'an in portions

f) Recite the selected Surah

g) State the teachings of the given Surah.

\subsection{Content}

1.21 Ulumul Qur'an

a) Definition

b) Need for revelation

(Q7:2, Q7:203)

1.22 Revelation

a) Role of angel Jibril (Q16:102-103, Q26:192-

b) Revelation of the Qur'an in portions (Q25:32)

1.23 The study of selected surah

a) Al-Fatiha (QI)

b) An-Nasir (QI 10)

c) Al-Fil (QIOS)

d) Al-Asr (Q103)

\subsection{HADITH}

\subsection{Specific Objectives}

By the end of the topic, the learner should be able to:

a) Define the term 'Hadith' 
b) Explain the evolution of Hadith

c) Discuss the importance of Hadith

d) Develop an awareness to observe Hadith in one's life.

2.20 Content

2.21 Definition of the term 'Hadith'

2.22 The evolution of Hadith:

a) Through the Prophet's own initiative.

b) As response to questions of his companions.

c) As a demand of circumstances

d) As an interpretation of the Qur'an.

2.23 Forms of Hadith

a) Fiil

b) Taqrir

c) Sifat

2.24 Contribution of Hadith to Islamic thought and culture.

3.00 PILLARS OF IMAN (FAITH)

3.10 Specific Objectives

By the end of the topic, the learner should be able to:

a) Explain the meaning of Tawheed

b) State the attributes of Allah (S.W.T)

c) Identify the significance of Tawheed

d) Define the term 'shirk' and its manifestation

e) Appreciate the relevance of Tawheed in the life of a Muslim

f) Explain the characteristics of angels

g) Mention at least ten angels

h) State the various functions of angels.

3.20 Content

3.21 Tawheed

a) The meaning of Tawheed (Q.112)

b) Attributes of Allah (S.W.T)

c) The significance of Tawheed.

3.22 Shirk and its manifestations

a) Shirk

b) Forms of shirk

(i) Shirk Akbar (Q31:13, 5:72, 16:51)

(ii) Shirkul Asghar (Riyaa)

c) Qur'anic condemnation of shirk (Q31:13)

3.23 Belief in angels

a) Characteristics of angels (Q66: 6)

b) Names of angels and their specified duties

(Q50:17-18)

i) Jibril

ii) Mikail

iii) Israfil

iv) Izrail

v) Atid and Raqib

vi) Munkar and Nakir

vii) Ridhwan and Malik

\subsection{DEVOTIONAL ACTS}

4.10. Specific Objectives

By the end of the topic, the learner should be able to:

a) Pronounce the shahada correctly

b) Explain the meaning of shahada

c) Discuss the significance of shahada in the life of a Muslim

d) State the meaning of swalat

e) Describe the significance of swalat 
f) Explain the importance of twahara

g) Perform correctly the acts of twahara

h) Mention the different types of swalat

i) Explain the importance of swalatul Jam'aa

j) Describe the various ways of performing swalatul musafir

k) Identify types of prayers for different occasions

I) explain the different types of sijda

4.20 Content

4.21 Shahada (declaration of creed)

a) Measuring of shahada

b) Significance of shahada

4.22 Swalat (Prayer)

a) Ghusul

b) Wudhu

c) Tayyamum

4.23 Significance of swalat (Q4: 103)

4.24 Types of Swalat

a) Faradh-ain (Q 238-239; Q11: 114)

b) Faradhul Kifaya

c) Sunna prayer

i) Tahiyyatul masjid

ii) Qabliyya and Baadiyya

iii) Taraweh

vi) Dhuhaa

4.25 Swalatul Jamaa (congregational prayers) and their importance

4.26 Prayers on special occasions

a) Swalatul Musafir

b) Jam'u Taqdim

c) Jam'u Taakhir

d) QasrQ4:101

e) Kusuf wal khusuf (prayers during the eclipses)

f) Swalatul Istisqai (prayers for rain)

g) Sijdat (prostration) (Q13 15)

i) Sijdatu Tilwawa

ii) Sijdatu Shukr

iii) Sijdatu Sahwu

5.00 ZAKAT (ALMS)

5.10 Specific Objectives

By the end of the topic, the learner should be able to:

a) Define the term 'zakat'

b) Explain the types of zakat

c) Differentiate between zakat and sadaqa

d) Discuss the importance of zakat

e) Identify the conditions for zakat payment

f) List down the items on which zakat is payable

g) State the recipients of zakat

h) Outline the nisab for various categories of items

i) Discuss the difference between zakat and tax

j) Appreciate the role that zakat plays in promoting integrity.

5.20 Content

5.21 a) Meaning of zakat and sadaqa (Q2:43), (Q2:110)

b) Types of zakat

i) Zakatul Maal

ii) Zakatul Fitr

iii) Sadaqa

5.22 Difference between zakat and sadaqa. 
5.23 Conditions for zakat.

a) Payment

b) Distribution

5.24 Recipients of zakat (Q9:60)

5.25 Importance of zakat

5.26 Difference between zakat and tax

5.27 Zakat and integrity

6.00 AKHLAQ

6.10 Specific Objectives

By the end of the topic, the learner should be able to:

a) Explain the basic principles of Islamic morality

b) Identify the dynamics of Islamic morality

c) Explain the significance of Islamic morality

d) Develop the virtue of commanding good and condemning evil.

6.20 Content

6.21 Essential components of Islamic morality

6.22 Dimensions of Islamic morality

a) Maarufat (virtues)

b) Muunkaraat (vices)

6.23 Significance of Islamic morality

6.24 Amr bil Maaruf wa Nahyi Anil Munkar (commanding good and forbidding evil) Q3: 104)

6.25 Morality based on

a) Iman (faith) Q103,

b) Salihat (good deeds) Q103, Q7:32-33

\subsection{MUAMALAT (RELATIONSHIP)}

\subsection{Specific Objectives}

By the end of the topic, the learner should be able to:

a) Explain the meaning of Nikah (marriage)

b) Describe the importance of marriage

c) State conditions for marriage

d) Discuss an Islamic marriage festival

e) Discuss the Islamic view on polygamy

f) Discuss the rights and duties of family members.

7.20 Content

7.21 The family as an important unit in the society

7.22 Nikah (marriage)

a) Purpose of marriage

b) Conditions and regulation of marriage

7.23 Polygamy

a) Conditions for polygamy (Q4:3)

b) Reasons for polygamy

c) Marriage of Prophet Muhammad (p.b.u.h)

i) Names of the wives

ii) The rationale

7.24 Rights and duties of family members

a) Parents (Q17:23-24, Q31:14-15)

b) Husband

c) Wife

d) Children

e) Extended family members

\subsection{HISTORY OF ISLAM}

\subsection{Specific Objectives}

By the end of the topic, the learner should be able to:

a) Describe the conditions of pre-Islamic Arabia

b) Narrate the life history of the Prophet (p.b.u.h) 
c) Outline the prophet's mission in Makka and Madina

d) Discuss the achievements of Prophet Muhammad (p.b.u.h.)

\subsection{Content}

8.21 Pre-Islamic Arabia

a) Jahiliyya

b) Prevailing conditions in Pre-Islamic Arabia

8.22 Life history of Muhammad

a) Birth

b) Early life

8.23 Prophet's Mission in Makka

a) Ba'ath (prophethood) and Revelation

b) Early Muslim community and persecution

c) Muslims seeking asylum in Abyssinia

d) Isra wal Miraj (night journey and ascension)

8.24 Prophet's mission in Madina

a) Hijra (migration to Madina)

b) Beginning of Muslim ummah

c) The battles of Badr, Uhud, Khandaq and Khaybar

d) The Treaty of Hudaibiyya

e) Conquest of Makka.

f) The battle of Hunain

g) Hijjatul widaa (The farewell pilgrimage)

h) Death of the Prophet

8.25 Achievements of the Prophet

a) Brotherhood and equality of mankind

b) Elimination of racism

c) Eradication of slavery

d) Improvement of the status of women

e) Religious tolerance

\subsection{MUSLIM SCHOLARS}

9.10 Specific Objectives

By the end of the topic, the learner should be able to:

a) Describe the early life of Sheikh Al Amin Mazrul and Sheikh Abdallah Swaleh Farsy

b) Explain their contributions to the growth and development of Islam

c) Appreciate and emulate these scholars.

9.20 Content

9.21 Sheikh Al-Amin Mazrui

a) Birth and early life

b) Educational background

c) Work and personal life

d) Achievements and

e) Contributions

9.22 Sheikh Abdallah Swaleli Farsy

a) Birth and early life

b) Educational background

c) Work and personal life

d) Achievements and contributions

\section{FORM TWO}

\subsection{QURAN}

10.10 Specific Objectives

By the end of the topic, the learner should be able to:

a) Define the term 'Wahyi'

b) Explain the modes of wahyi

c) Explain the modes of revelation of the Quran

d) Outline the process of compilation of the Quran

e) Recite and explain the meaning of selected verses 
1) Appreciate the lessons derived from the selected verses.

10.20 Content

10.21 Ulumul Quran - Wahyi and its modes

10.22 Revelation of the Quran

10.23 Recording and compilation of the Quran

10.24 Study of selected verses i.e.

a) Ayatul Kursi (Q2:255)

b) The last verses of Al-Baqarah (Q2:284-286)

\subsection{HADITH}

11.10 Specific Objectives

By the end of the topic, the learner should be able to:

a) Define the term 'Muhaddith'

b) Describe the factors that contributed to the growth of hadith

c) Discuss the significance of hadith

d) Describe the general features of hadith

11.20 Content

11.21 Ulumul Hadith - Meaning of the term 'Muhaddith'

11.22 Growth and development of hadith

11.23 Significance of Hadith (Q3:31 - 33; Q33:21)

11.24 Components of Hadith

a) Isnad

b) Matn

\subsection{PILLARS OF IMAN (FAITH)}

12.10 Specific Objectives

By the end of the topic, the learner should be able to:

a) Explain the need for divine guidance

b) Identify the revealed scriptures and their prophets

c) Discuss the uniformity of the content of the revealed scriptures

d) Explain the role of prophets in facilitating divine guidance

e) Name the prophets mentioned in the Quran

f) Describe the characteristics of the prophets

g) Discuss the finality of prophet Muhammad (S.A.W.)

h) Mention the Ulul-azm prophets

i) Describe Islamic death and life after death

j) Explain the Islamic teach on A'dl (Divine justice)

k) Appreciate the Islamic teachings on reward and punishment.

12.20 Content

12.21 Need for Divine guidance (Q2:213)

12.22 Revealed scriptures (Q2:136 Q87:18-19)

12.23 Characteristics of the prophets (Q6:48 Q14:4)

12.24 Prophets mentioned in the Quran Ulul Azm prophets

12.25 Ulul Azm prophets

12.26 Finality of Prophet Muhammad (S.A.W) (Q33:40)

12.27 Belief in Qiyama

a) Death (3:185)

b) Life after death

(i) Barzakh (Q23:100)

(ii) Resurrection (Q17: 49-52)

(iii) Judgment (Q3: 185)

(iv) Paradise and Hell (Q98: 6-8)

12.28 Quranic concept of AdI (Divine Justice) (Q36: 5 1-54)

12.29 Significance of the belief of Qiyama in the life of a Muslim

\subsection{DEVOTIONAL ACTS}

13.10 Specific Objectives

By the end of the topic, the learner should be able to:

a) Define the term "saum" explain the significance of saum. 
b) Mention the types of saum.

e) Identify persons exempted from saum.

d) List down the nullifiers of saum,

e) Define Hajj and explain its significance.

f) Explain the conditions for the preparation of Hajj.

g) Identify the types of Hajj.

13.20 Content

13.21 As-Saum (fasting)

13.22 The meaning of saum

13.23 significance of saum (Q2:183)

a) Fardh

b) Qadha

c) Kafara

d) Sunnah

e) Nadhir

13.25 Persons exempted from saum

13.26 Nullifiers of saum

13.27 Significance of the Holy month of

Ramadhan. (Q2: 185, Q97)

13.28 Hajj (Pilgrimage)

13.29 Meaning of Hajj

13.30 Significance of Hajj (Q3:96-97, Q22:27-29)

13.31 Conditions for the preparation of Hajj

13.32 Types of Hajj

a) Qiran

b) Ifrad

c) Tamattu

13.33 Performance of Hajj and Umra (Q2:158, Q2:196)

13.34 Visit to Medina

14.00 AKHLAQ (MORAL VALUES)

14.10 Specific Objectives

By the end of the topic, the learner should be able to:

a) Identify deeds that lead to piety and righteousness

b) Name immoral trends in the society

c) Explain the rationale for the prohibition of immoral

d) Discuss the effects of these vices to the society

e) Adopt upright Islamic morals and refrain from immoral

14.20 Content

14.21 Husnul-Khulq (virtues)

14.22 Deeds leading to piety and righteousness (Q2: 177)

14.23 Self-control (Q29:69)

14.24 Sakina (tranquillity) (Q 16:106)

14.25 Qanaa'a (contentment)

14.26 Sabr (Patience) (Q2:153, Q103)

14.27 Amana (Trust) (Q4:58 Q2:283)

14.28 Sidq (Truthfulness) (Q9: 119, Q33:35)

14.29 Su-uI Khulq (vices)

14.30 Intoxicants (Q5: 90-91)

14.31 Gambling (Q2: 219)

14.32 Kibr (Pride) (Q3 1:18)

14.33 Drug abuse (Q2: 195)

14.34 Sexual perversion

a) Zinaa (Q17:32 Q24:2-3)

b) Prostitution

c) Homosexuality (Q7:80-84)

d) Incest 
e) Bestiality

f) Rape

14.35 Effects of sexual perversions in society

15.00 MUAMALAT (RELATIONSHIPS)

15.10 Specific Objectives

By the end of the topic, the learner should be able to:

a) Explain Talaq and its effects on the society.

b) Describe the machinery of Talaq.

c) Identify the types of eddat.

15.20 Content

15.21 Meaning of Talaq (Q2:228-229), (Q4:34), (Q65: 1-4)

15.22 Machinery for Talaq (Q4:34-35)

15.23 Types of talaq i.e.

a) Talaq by husband

b) Khulu

c) Muharat

15.24 Effects of talaq

15.25 Types of lddah and its importance (Q4:34). (Q65: 1-4)

15.26 Observance of Iddah (Q65: 1-7)

16.00 HISTORY OF ISLAM (THE RIGHTLY

GUIDED CALIPHS)

16.10 Specific Objectives

By the end of the topic, the learner should be able to:

a) Give a brief biography of the four rightly guided Caliphs

b) Discuss the various challenges faced by Caliphs

c) Outline their achievements

d) Explain the spread of Islam in East Africa

e) Discuss the influence at the East Coast of Africa

16.20 Content

16.21 Abu Bakar As-Siddiq (R.A)

a) Early life

b) Conversion to Islam

c) Companionship to the prophet

d) Accession to caliphate

e) Challenges

f) Death

g) Achievements

16.22 Umar Bin Khattab (R.A)

a) Early life

b) Conversion to Islam

c) Companionship to the prophet

d) Accession to caliphate

e) Challenges faced

f) Death

g) Achievements

16.23 Uthman Bin Affan (R.A.)

a) Early life

b) Conversion to Islam

c) Companionship to the prophet

d) Accession to caliphate

e) Challenges faced

f) Death

g) .Achievements

16.24 Ali Bin Abi Talib (R.A.)

a) Early life

b) Companionship to the prophet 
c) Accession to caliphate

d) Challenges

e) Death

f) Achievements

16.25 Islam in East Africa

16.26 The first Muslim contact with the coast of

East Africa

a) Conditions of East Africa before contact with Muslim

b) Muslim city states e.g. Mogadishu, Kilwa and Sofala

c) The Swahili

d) Islam during the Portuguese rule in the East Coast of Africa

e) Modes of Islamisation

f) Influence of Islam at the Coast.

\subsection{MUSLIM SCHOLARS}

17.10 Specific Objectives

By the end of the topic, the learner should be able to:

a) Give a brief biography of

i) Sayyid Qutb and

ii) Hassan al Banna

b) Outline their works and contribution to Islam.

c) Appreciate and aspire to emulate them.

17.20 Content

17.21 Sayyid Qutb

a) Life history

b) Contribution

17.22 Hassan al Banna

a) Life history

b) Contribution

FORM THREE

18.00 QURAN

18.10 Specific Objectives

By the end of the topic, the learner should be able to:

a) Explain the modes of the preservation of the Quran

b) Discuss the circumstances that led to the standardization of the Holy Quran

c) Describe the Quran as a Book of guidance

d) Explain the teachings of the selected surah.

18.20 Content

18.21 Preservation of the Quran (Q15: 9)

a) The time of the prophet

b) Caliphs' time

c) Present time

18.22 Standardization of the Quran

a) Circumstances that led to the standardization of the Quran during the reign of Caliph Uthman (R,A.)

b) The process of standardization of the Quran

c) Diacriticalization of the Quran

18.23 Surah An Nur (Q24)

a) Meaning of the verses

b) Teachings of the Surah

19.00 HADITH

19.10 Specific Objectives

By the end of the topic, the learner should be able to:

a) Identify the types of hadith

b) Explain simple classification of hadith

c) Identify the main Sunni and Shia collections of hadith

d) Appreciate the role played by the compilers of hadith

e) Develop spiritual and moral values through hadith. 
19.20 Content

19.21 Types of hadith

a) Hadith Nabawi

b) Hadith Qudsi

c) Difference between Hadith Qudsi and Hadith Nabawi

19.22 Classification of hadith

a) Tests to determine the authenticity of hadith

b) Simple classification of hadith

i) Sahih

ii) Hassan

iii) Dhaif

19.23 Sunni and Shia collection of hadith

a) Sahihul.-Sitta (the six Sunni collection of hadith)

i) Sahih Bukhari

i) Sahih Muslim

ii) Sunan Ibn Majah

iii) Sunan Abu Daud

iv) Sunan Nasai

v) Jamii Tirniidhi

b) Al Kutub al arba (the four Shia collection of hadith)

i) Al Kafi (the compendium) of Muhammad Yaqub al-Kulaini

ii) Man Ia yahdurul-Faqih by Abu Jaafar Muhammed Ibn Hassan at Tusi

iii) Tahdhibul Ahkam by Abu Jaafar Muhammad Ibn Hassan at Tusi

iv) Al-Istibsar by Abu Jaafar Muhammed Ibn Hassan at Tusi

c) Three later books of the Shia

i) Biharul Anwar (oceans of light) by Mulla Muhammad Baqir Majlisi

ii) Al Wafi by Muhammad bin Murtaza

iii) Wasa-il-ush-Shia by Muhammad bin Hassan al Hur

19.24 Study of some selected hadith

a) Talabul Ilm (Seeking Knowledge)

b) An Niyyah (intention)

c) Tawakkul (Reliance on Allah)

\subsection{PILLARS OF IMAN (FAITH) IMAMAH}

(SHIA BELIEF)

20.10 Specific Objectives

By the end of the topic, the learner should be able to:

a) Discuss various interpretations of the term 'Imam'.

b) Describe the concept of Imamah as a fundamental Shia doctrine

c) Discuss the appointment of an Imam.

d) Outline the qualities of an lmam.

e) Explain the significance of an Imam.

20.20 Content

Imamah

20.21 Different interpretations of the term 'Imam'

a) Ordinary meaning of Imam (i.e. leader of swalat)

b) Shia concept of an Imam

20.22 The doctrine of Imamah

a) Appointment of the Imam

b) Declaration of Ali bin Abi Talib at Ghadir Khum

c) Qualities of an Imam

d) Duties and significance of an Imam

\subsection{DEVOTIONAL ACTS}

21.10 Specific Objectives

By the end of the topic the learner should be able to:

a) Explain the meaning of sharia and fiqh

b) Discuss the sources of sharia 
c) Explain the development of fiqh (Islamic jurisprudence)

d) Give a brief survey of the life and contributions of the five Imams of fiqh

e) Distinguish between Deen and Sharia

f) Discuss the nature and purpose of sharia

g) Describe the historical development of sharia

h) Appreciate the sharia as a divine gift.

\subsection{Content}

21.21 Meaning of the terms:-

a) Sharia

b) Fiqh

21.22 Sources of sharia

a) Primary sources (Q16:44, Q53:3-4)

i) Quran

ii) Hadith

b) Secondary sources

i) Ijma

ii) Qiyas

c) Ijtihad (a process of deducing judgement from the sources of shariah)

21.23 Fiqh

a) Historical development of fiqh (Islamic jurisprudence)

b) Brief survey of the life of the f Imams of Fiqh

i) Imam Abu Hanifa

ii) Imam Malik

iii) Imam Shafti

iv) Imam Ahinad bin Hanbal

v) Imam Jafar As-Sadiq

21.24 Nature and purpose of Sharia

a) Rights of Allah

b) Rights of self

c) Rights of other people

d) Rights of other creatures

\subsection{AKHLAQ (MORAL)}

22.10 Specific Objectives

By the end of the topic the learner should be able to:

a) Identify the positive and precautionary aspects of Islamic morality

b) Explain the dimensions of Islamic virtues

c) Explain the significance of preventive precautionary morality in Islam.

22.20 Content

22.21 Positive aspects of morality in Islam

a) Sadaqa of the tongue

b) Appreciation and gratitude (shukr)

c) Forgiveness

d) Justice (Adl) (Q5:8,)

22.22 Dimensions of Morality in Islam

a) Spiritual observance (e.g. swalat, zakat, etc) and their moral implications (Q2:183, Q29:45)

b) Preventive and precautionary morality

i) Prohibitions on certain foods and drinks (Q5:3, Q5:90)

ii) Vain talks (Q23:3, Q3

iii) Abortion (Q6:15 (81:8-9)

iv) Slander (Q24:4, Q24:23)

v) Israf Extravagance) (Q25: 67)

c) Islamic manners on

i) Walking (Q31:18)

ii) Eating

iii) Sleeping

iv) Islamic mode of dress (Q7: 26), (Q16: 81) (Q24: 31) 


\subsection{MUAMALAT (RELATIONSHIP)}

23.10 Specific Objectives

By the end of the topic, the learner should be able to: -

a) Explain the meaning of the term .mirath

b) Discuss the essentials and conditions of mirath

c) Discuss the significance of inheritance

d) Explain the administration of the estate of a deceased Muslim

e) Describe the importance of wasiya

f) Identify the main categories of heirs and their shares.

23.20 Content

23.21 Mirath

a) Meaning of mirath

b) Significance of the law of mirath

c) Essentials of inheritance

i) Deceased person

ii) Heir

iii) Estate

d) Conditions for Mirath (inheritance)

i) Death of a person who leaves behind properties

ii) Survival of heirs

iii) Existence of the estate

23.22 Administration of the estate (Q4:11)

a) Funeral expenses

b) Debts

c) Wasiya

23.23 Wasiya (Will) (Q4:11-12), (Q2:180-181)

a) Conditions for wasiya

b) Significance of wasiya

23.24 Heirs and their shares (Q4: 1 1-12), Q4.176

24.00 TIJARA (TRADE AND COMMERCE)

24.10 Specific Objectives

By the end of the topic the learner should be able to:

a) Explain the Islamic teachings on the acquisition and ownership of property

b) Identify legitimate sources of earnings

c) Explain the significance of upholding ethical values in commercial enterprise

d) Discuss the components of agreements and contracts in Islam

e) Identify lawful and unlawful acts in trade

f) Appreciate the value of observing integrity

g) Describe the evil of corruption.

24.20 Content

24.21 Wealth and property

a) Islamic teachings on the acquisition of wealth

b) Source of earnings

i) Legitimate

ii) Illegitimate

21.22 Trades and Commerce

a) Honesty in trade (Q83:1-3)

b) Record keeping (Q2:283)

c) Lawful and unlawful acts in trade

i) Money lending

ii) Riba (interest) (Q2:275-278)

iii) Hoarding (Q9:34)

iv) Buying and selling

v) Monopoly

24.23 Agreements and contracts

a) Conditions 
b) Factors that invalidate contracts and agreements 24.24 Corruption

a) Causes

b) Effects

c) Remedies

\subsection{HISTORY OF ISLAM}

25.10 Specific Objectives

By the end of the topic, the learner should be able to:

a) Outline the causes of the rise of Ummayyad dynasty

b) Discuss administration under the Ummayad

c) Explain the factors that led to their decline

d) Examine the contributions of the Ummayyad

e) Describe the biographies of the selected Ummayad rulers.

25.20 Content

25.21 The rise of the Umayyad

25.22 Administration of the Ummayyad

25.23 Decline of the Ummayad

25.24 Achievements of the Ummayad

25.25 Selected Ummayyad rulers

a) Mu'awiyah bin Abu Sufyan

b) Yazid bin Mu'awiya

c) Abdul Malik bin Marwan

d) Umar bin Abdulaziz

26.00 ISLAM IN EAST AFRICA

26.10 Specific Objectives

By the end of the topic, the learner should be able to:

a) Explain the factors that influenced the spread of Islam in the interior of Kenya, Uganda and Tanzania

b) Examine the contributions of Muslims in these regions

c) Identify the challenges faced by Muslims in these regions

26.20 Content

26.21 Spread of Islam in the interior of Kenya

a) North Eastern b) Central c) Western Kenya

26.22 Islam in Uganda

a) The role of Kabaka Mutesa I

b) The influence of Christianity in Uganda

26.23 Spread of Islam in the interior of Tanzania
a) Tabora
b) Ujiji

c) The role of Akidas and Jumbes

26.24 Contributions of Muslims in East Africa

a) Political

b) Social

c) Economic

26.25 Challenges faced by Muslims in East Africa

\subsection{MUSLIM SCHOLARS}

\subsection{Specific Objectives}

By the end of the topic, the learner should be able to:

a) Give brief biographies of selected scholars

b) Discuss their works and contributions

c) Appreciate and aspire to emulate them.

27.20 Content

27.21 Uthman Dan Fodio

a) Life

b) Works and contributions

27.22 Al-Ghazali

a) Life history

b) Works and contributions 


\section{FORM FOUR \\ 28.00 QURAN}

28.10 Specific Objectives

By the end of the topic, the learner should be able to

a) Explain the distinctive features of the Qur'an

b) Describe the conditions and benefits of translating the Qur'an

c) Appreciate the Qur'an as the final revelation

d) Explain the teachings of suratul Hujurat (Q49)

28.20 Content

28.21 Distinctive features of the Qur'an

a) Divisions of the Qur'an

b) Makka and Madina surah

(i) Language and style (Q12:2,) (Q1 3:37:,)

(Q41:44,) (Q18:1-2,) (Q41:42)

(ii) Miraculous nature of the Qur'an

28.22 Tarjamatul Quran (Translation of Qur'an)

a) Conditions for translation

b) Benefits of translation

c) Problems in translating the Qur'an

28.23 Qur'an as the final and perfect revelation

28.24 Teachings of suratul Hujurat (Q49)

\subsection{HADITH}

29.10 Specific Objectives

By the end of the topic, the learner should be able to:

a) Describe the role played by the compilers of Hadith

b) Discuss the lessons of the selected Hadith

c) Acquire spiritual and moral values through Hadith.

29.20 Content

29.21 Other collections of Hadith

a) Al Muwatta

b) The forty hadith of Imam Nawawi

29.22 Study of some selected hadith

a) Work as a form of Ibada

b) Anger, envy and jealousy

c) Care for orphans, disabled and the aged

d) Care for animals and plants

\subsection{PILLARS OF IMAN (FAITH)}

\subsection{Specific Objectives}

By the end of the topic, the learner should be able to:

a) Explain the significance of the belief in Qadar

b) Appreciate the eternity of Allah and His power.

30.20 Contents

30.21 Meaning of Qadar and Qadha

30.22 Significance of the belief in Qadar

\subsection{DEVOTIONAL ACTS}

31.10 Specific Objectives

By the end of the topic, the learner should be able to:

a) Identify the categories of legal acts in the Islamic law

b) List the crimes and punishments under the sharia

c) Explain the rationale of punishment under the Islamic sharia

d) Differentiate between Islamic sharia and secular law

e) Differentiate between sin and crime

f) Explain the functions of the Kadhi

g) Explain the meaning and conditions for Tawba.

31.20 Content

31.21 Classification of legal acts (Ahkamu-sharia) 
a) Fardh and Wajib

b) Sunnah

c) Sahih and Bath

d) Halal and Haram

e) Makruh

f) Mubah

31.22 Islamic criminal law: Allah as the sole lawgiver

31.23 Classification of crimes and punishments

a) Hudud e.g. zinaa, theft (Q24:2, Q5:38)

b) Qisas (Q2:178-179)

c) Taazir

31.24 Relevance of Islamic criminal Law

31.25 Islamic sharia and secular laws

31.26 The concept of sin and crime

31.27 Administration of justice

a) The Kadhi

b) Rules of evidence

31.28 Concept of Tawba

a) Meaning of Tawba (Q24: 5, Q42: 25)

b) Conditions for Tawba

c) Significance of the concept of Tawba in Islam

32.00 AKHLAQ (MORAL VALUES)

32.10 Specific Objectives

By the end of the topic the learner should be able to:

a) Identify the causes and effects of STDs, and HIV/AIDS

b) Mention the causes and effects of drug abuse

c) Explain the importance of environmental conservation

d) Observe Islamic moral values.

32.20 Content

32.21 a) causes and effects of STD's, HIV/AIDS

i) Causes

ii) Effects

b) Causes and effects of drug abuse

i) Causes

ii) Effects

32.22 Importance of environmental conservation

32.23 Islamic views on:

a) HIV/AIDS

b) Drug abuse

c) Conservation of the physical and moral environment

32.24 Detention of Islamic cultural values in the changing society.

\subsection{MUAMALAT (RELATIONSHIP)}

\subsection{Specific Objectives}

By the end of the topic, the learner should be able to:

a) Describe Islamic teachings on co-existence with non- Muslims.

b) Explain the position of Islam on the status of women.

c) Explain the Islamic teachings on child care and domestic harmony.

d) Appreciate the need for peaceful co-existence among people of different nations.

33.20 Content

33.21 Relationship between Muslims and non- Muslims (Q49:14, Q29:46)

33.22 Status of women

33.23 Child abuse, labour and neglect

33.24 Domestic violence.

33.25 Islamic relations with other nations

a) Basic principles on Islamic international relations

b) Misconceptions about Islam 
i) Jihad

ii) Terrorism

iii) Slavery

34.00 HISTORY OF ISLAM

34.10 Specific Objectives

By the end of the topic, the learner should be able to:

a) Discuss the rise of the Abbasid and Fatimid dynasties

b) Outline the achievements of the Abbasid and Fatimid dynasties

c) Narrate the biographies of the selected Abbasid rulers.

34.20 Content

34.21 Abbasid Dynasty

a) Rise

b) Decline

c) Achievements

34.22 Selected Abbasid rulers

a) Abul Abbas

b) Harun Ar-Rasheed

c) Ma'mum Ar-Rasheed

34.23 Fatimid Dynasty

a) Rise

b) Decline

c) Achievements

35.0.0 MUSLIM SCHOLARS

35.1.0 Specific Objectives

By the end of the topic, the learner should be able to:

a) Give a brief biography of Ibn Sina, Ibn Khaldun

b) Outline their works and contributions to Islam,

c) Appreciate and aspire to emulate them

d) Appreciate the contributions of Muslim scholars to science.

35.20 Content

35.21 Ibn Sina

a) Life history

b) Contribution

35.22 Ibn Khaldun

a) Life history

b) Contribution

35.23 Muslims contribution to Science.

SUGGESTED LEARNING AND TEACHING

EXPERIENCES

1. Memorizing

2. Discussing

3. Identifying

4. Explaining

5. Outlining

6. Note making

7. Experience sharing

8. Narrating

9. Visiting

10. Role playing

11. Dramatizing

12. Reciting

LEARNING AND TEACHING RESOURCES

The suggested learning and teaching resources in Islamic Religious Education are neither exhaustive nor prescriptive. A wealth of other learning/teaching resources will be explored through sharing of experiences with colleagues within schools and other institutions of learning. Some of the resources could be improvised or prepared 
through project work. Other resources may be collected during field trips and those that are unaffordable could be borrowed or shared.

The suggested resources include:

I. The Holy Quran

2. Collections of Hadith

3. Resource persons

4. Maps, charts, diagrams, pictures

5. Audio visual cassettes

6. Flash cards

ASSESSMENT

Assessments are essential elements of teaching as they enable the teacher to evaluate the achievement of objectives by the learner. Thus a variety of assessment methods have to be used to ensure that all the objectives of the syllabus have been achieved.

\section{SUGGESTED MODES OF ASSESSMENT}

\section{INCLUDE}

1. Oral and written tests

2. Quizzes

3. Observation

4. Recitation competitions

5. Project work

6. Essays

\section{APPENDIX VI:}

\section{Context for the Secondary Education Strategy}

The Importance of Secondary Education The global growth in demand for Secondary Education is driven by five key factors: (i) The huge bulge in the number of students completing primary; (ii) An increasing demand for new types of skills and knowledge; (iii) A growth in the service sector and its requirement for - knowledge workers'at the expense of the government or agrarian sectors; (iv) A democracy's need for better educated citizens. (v) The increasing private returns of secondary education as the labour market demands graduates with a set of knowledge and competencies that can only start to be acquired at the secondary education level and beyond. Yet the clear rationale for investing in secondary education can also be understood for a number of additional reasons that highlight how education at this secondary level contributes to individual earnings and overall national economic growth. Specifically the reasons include:

$\square$ Growth and poverty reduction: Secondary education plays a particularly important role in increasing economic growth since this economic growth is shown to have a positive correlation to years of school attainment.

$\square$ Need for a balance: Historically countries that have experienced the most rapid and sustainable increases in educational attainment, as well as outstanding economic performance, have pursued a balanced upgrading of the primary, secondary, technical and tertiary levels of education.

$\square$ The sub-sectoral bridge: Within any education system, secondary education is the bridge between primary schools, tertiary institutions and the world of work. Secondary education can provide a set of pathways for progress or the bottleneck that prevents an equitable expansion of education opportunities. Further, increasing the provision and coverage of secondary education has been clearly shown to boost completion rates in primary education. In fact secondary education must be viewed as an essential incentive for primary completion.

$\square$ Developer of social capital: Education contributes to the development of social capital by increasing an individual's propensity to trust and be tolerant of others.

$\square$ Gender equality: Findings are that investments in female education have a positive impact on gender equality, women's empowerment and well-being. Further, that the higher the levels of education, the greater the benefits on women's own health outcomes from risks of disease.

$\square$ Socio-economic equality: Any consideration of equity in education must obviously address issues related to outcomes as well as to merely access. National educational policy and practice assists in mitigating the influence of social and economic privilege on education achievement.

Source: MoE (2007) Secondary Education Strategy, p. 2

\section{APPENDIX VII:}

A Sample of IIEP Timetable 